\title{
Sri Lanka: Second and Third Reviews Under the Stand-By Arrangement-Staff Report; Press Release on the Executive Board Discussion; and Statement by the Executive Director for Sri Lanka.
}

In the context of the second and third reviews under the stand-by arrangement, the following documents have been released and are included in this package:

- $\quad$ The staff report for the Second and Third Reviews under the Stand-By Arrangement, prepared by a staff team of the IMF, following discussions that ended on May 21, 2010, with the officials of Sri Lanka on economic developments and policies. Based on information available at the time of these discussions, the staff report was completed on June 21, 2010. The views expressed in the staff report are those of the staff team and do not necessarily reflect the views of the Executive Board of the IMF.

- $\quad$ A Press Release summarizing the views of the Executive Board as expressed during its June 28, 2010 discussion of the staff report that completed the review.

- $\quad$ A statement by the Executive Director for Sri Lanka.

The documents listed below have been or will be separately released.

Letter of Intent sent to the IMF by the authorities of Sri Lanka*

Memorandum of Economic and Financial Policies by the authorities of Sri

Lanka*

Technical Memorandum of Understanding*

*Also included in Staff Report

The policy of publication of staff reports and other documents allows for the deletion of market-sensitive information.

\author{
Copies of this report are available to the public from \\ International Monetary Fund • Publication Services \\ $70019^{\text {th }}$ Street, N.W. $\bullet$ Washington, D.C. 20431 \\ Telephone: (202) 623-7430 • Telefax: (202) 623-7201 \\ E-mail: publications@imf.org Internet: http://www.imf.org
}

\section{International Monetary Fund Washington, D.C.}




\section{INTERNATIONAL MONETARY FUND}

\section{SRI LANKA \\ Second and Third Reviews Under the Stand-By Arrangement}

Prepared by the Asia and Pacific Department in Consultation with Other Departments

Approved by Kalpana Kochhar and Dominique Desruelle

June 21,2010

Stand-By Arrangement: A 20-month Stand-By Arrangement in the amount of SDR 1.65 billion (400 percent of quota) was approved by the Executive Board (IMF Country Report No. 09/310) on July 24, 2009, and a first purchase of SDR 206.7 million was made following the completion of the first review (IMF Country Report No. 10/260) on November 6, 2009.

Economic developments: Overall economic conditions are improving as expected, and the economy is likely to show strong growth this year. Inflation remains subdued and average inflation for the year as a whole is expected to remain in the single digits. External balances are strong, remittance inflows continue at a high rate, tourism prospects continue to improve rapidly, and gross reserves remain at comfortable levels.

Program performance: The program has been on hold for several months following the non-observance of the end-December domestic budget borrowing ceiling, with the deficit reaching nearly 10 percent of GDP against a program target of 7 percent. The main factors for the overrun were faster-than-expected infrastructure project disbursements, higher interest payments, weak revenue, and post-conflict rehabilitation spending. Since then all end-March performance criteria have been met. In view of the December breach of the deficit target, election-related delays in preparing the 2010 budget and implementing tax reforms, and the authorities' extensive reform agenda in 2011, the government has requested that the SBA be extended by one year through end-2011.

Discussions: A staff team consisting of Messrs. Aitken (Head), Nyberg, Ding (APD), Dwight (SPR), and Peiris (MCM), visited Colombo on May 12-21, 2010. Mr. Mathai (Resident Representative) assisted the mission. Mr. Weerasinghe (OED) joined the discussions. The team held discussions with the Minister for Economic Development, the Deputy Minister of Finance, the Governor of the Central Bank of Sri Lanka, Secretary to the Treasury, representatives of the private sector and civil society, donors, and other officials. 


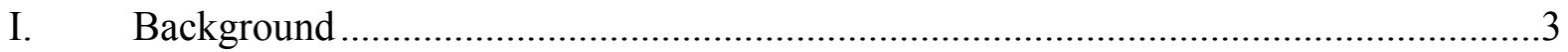

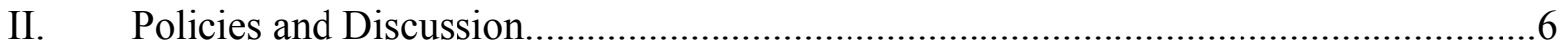

A. Improving the Investment Climate .............................................................6

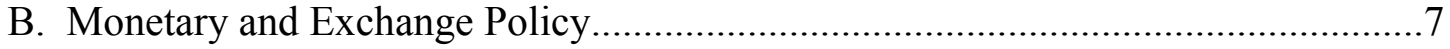

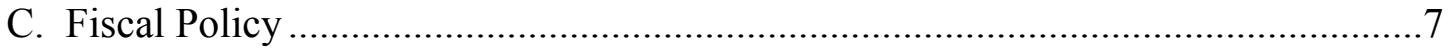

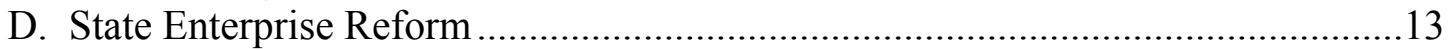

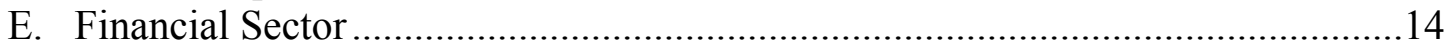

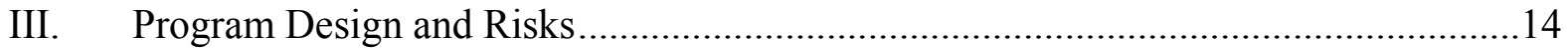

IV. Staff Assessment ......................................................................................... 15

Box

1. Background to the Presidential Tax Commission...................................................11

Figures

1. Economic and Program Performance ................................................................... 18

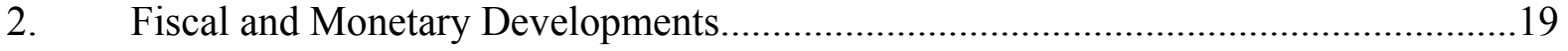

3. External and Financial Developments ...................................................................20

Tables

1. Selected Economic Indicators, 2008-2012 …....................................................21

2. Summary of Central Government Operations, 2008-2012 ...................................22

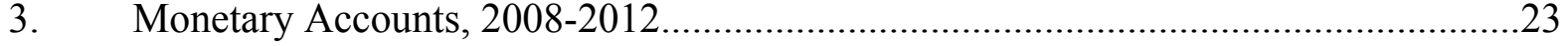

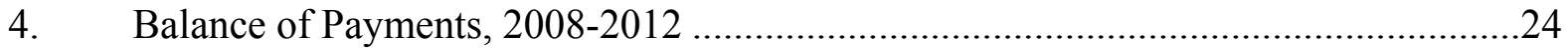

5. Preliminary External Financing Requirements, 2008-2012 _...............................25

6. Financial Soundness Indicators - All Banks ..................................................26

7. Reviews and Disbursements under the Proposed Stand-By Arrangement .................27

Attachments

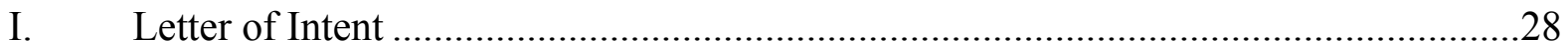

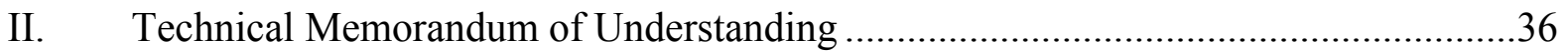




\section{BACKGROUND}

1. Context. The program has been on hold for several months following a significant breach of the end-December domestic budget borrowing ceiling, with the deficit reaching nearly 10 percent of GDP against a program target of 7 percent. Overall economic conditions are improving as expected, and the economy is likely to show strong growth this year, reaching $6 \frac{1}{2}$ percent driven by favorable developments in the agricultural, tourism, and service sectors. Inflation remains subdued in the single digits (Figure 1).

2. Political developments. President Rajapaksa was re-elected to a second six-year term in January by a sizeable majority. The ruling party's margin of victory in the April parliamentary elections fell just short of a two-thirds majority required for constitutional amendments. In April the president carried out his pre-election promise to significantly streamline the cabinet, and cut the number of ministerial posts from 90 to around 40 . The post-election appointments of key ministers - foreign, power, oil — as well as key postschairmen of the Board of Investment (BOI), the tourism board, the tea board, and the state oil company - are widely regarded as qualified professionals, most with private sector experience.

3. External sector. The current account remains strong as remittance inflows continue at a high rate and tourism arrivals are rapidly improving. The current account was roughly in balance in 2009 for the first time since 1984 mainly owing to a steep fall in imports.

However, high remittance flows, the pick-up in economic activity, and the expected response to the June trade liberalization (described in paragraph 19 below) are all likely to deliver strong import growth in the months ahead. Export growth has been slow to recover and clouded by the possibility of a withdrawal of the GSP+ concessions from the EU scheduled for August 2010, although negotiations for its renewal continue. The precise impact of a GSP+ withdrawal is not certain but is unlikely to be large economically. It could though have social consequences by affecting small employment-intensive producers.

\section{Monetary and exchange rate}

developments. Monetary conditions are stable (Figure 2). Reserve money continues to increase in line with expectations. All interest rates-policy rates, treasury bill rates, and lending rates - have declined significantly since early-2009, and have been relatively stable since late-2009. Credit growth has shown some signs of picking up in the period following the elections, and demand for loans has strengthened.

Sri Lanka: Interest Rates (in percent)

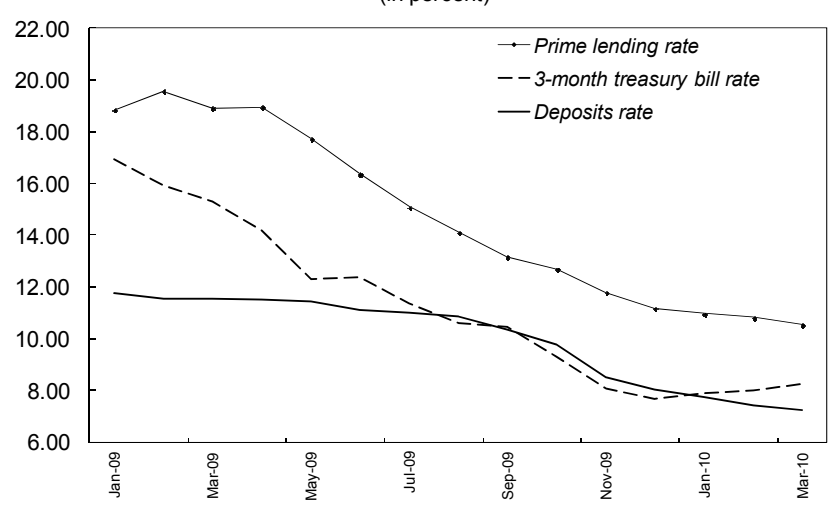

Following central bank intervention in the face of sharp increase in foreign investor interest 
and capital inflows in the second half of 2009, reserves have stabilized at about $\$ 5$ billionequivalent to over four months of imports - compared with $\$ 1 \frac{3 / 4}{4}$ billion projected for end2009 at the time of program approval. In rebuilding reserves, the central bank's intervention in the foreign exchange market has prevented foreign exchange inflows from appreciating the exchange rate, and the bank has allowed the rate to trade within a recently widened, although still narrow band (Figure 3).

5. Financial sector. Following the turmoil in 2009, financial sector conditions have stabilized. Non-performing loans have been on the decline since late-2009. The Sri Lankan stock market price index has doubled since the end of the war in May, reaching an all time high in recent weeks (Figure 3).

6. The 2009 budget outturn. The budget deficit in 2009 reached nearly 10 percent of GDP, against a program target of 7 percent. Domestic borrowing exceeded the program ceiling by just under 2 percent of GDP. The main factors for the overrun are:

- Capital spending was $1 \frac{1}{2}$ percent of GDP higher than anticipated. A large part of this is related to faster-than-programmed, lumpy disbursements for a couple of large foreign-financed infrastructure projects and their domestic counterpart funds (see paragraph 7 below).

- Interest payments exceeded original program projections by nearly 1 percent of GDP. As part of treasury's debt management strategy of replacing high interest treasury bills - originally scheduled to mature in 2010 — with longer maturity bonds, some cash payments were moved forward into 2009. The authorities also underestimated in the original budget interest payments implicit in the price of reissued treasury bonds.

- Other recurrent spending is a key determinant of the authorities' fiscal adjustment efforts. Excluding grant-related spending, this spending exceeded programmed levels by just under $1 / 2$ percent of GDP, mostly because of subsidies and transfers. About $1 / 4$ of this overrun was related to the resettlement of the war's internally displaced persons (IDPs).

- Lower revenue. Revenue lagged program projections by $1 / 4$ percent of GDP, mainly because higher revenue-yielding imports had not yet recovered.

7. Sources of higher capital spending. To help assess fiscal developments given the difficulty of predicting the timing of disbursements for large infrastructure projects, staff established a detailed project-by-project framework for monitoring specific foreign-financed project commitments and spending under the program, including for reconstruction in the north and east. This framework currently incorporates over 80 infrastructure projects either already underway or where financing is currently being sought, including some 35 for postwar reconstruction. Based on this framework, higher capital spending in 2009 relates to 
faster-than-programmed implementation of foreign-financed projects, including some $\$ 150$ million ( $1 / 2$ percent of GDP including domestic counterpart funds) in disbursements for the Chinese-financed southern port project which were not expected until early 2010.

8. Fiscal developments in 2010. Revenue has been increasing as a share of GDP broadly as projected, reflecting a modest increase in revenue-yielding imports. Spending through April was governed by the pre-election (vote-on-account) budget. With parliamentary passage of the full-year budget not expected until July, spending since April has been governed by a temporary presidential directive. According to the constitution, this directive gives the government the authority to limit spending on a discretionary basis. The authorities have indicated their intention to use this discretion to limit domestic borrowing to cover only debt service, which if carried out would imply an annualized deficit through July in the range of 7-8 percent of GDP. The authorities have committed in the LOI to limit spending under the decree to a level consistent with their overall 2010 deficit target (see paragraph 17 below). Domestic budget borrowing through early-June has been relatively tight, consistent with this deficit target.

9. Donor financing. The ADB recently approved a $\$ 50$ million loan to improve fiscal operations, and a $\$ 150$ million emergency loan for projects to support the rehabilitation of refugee communities in the north and east. The World Bank recently approved projects totaling \$108 million, consisting of \$50 million for north and east local service improvement, $\$ 40$ million for higher education, and $\$ 18$ million for sustainable tourism. Sizeable bilateral project loan disbursements from China, India, and Japan — primarily infrastructure-relatedcontinue.

10. Internally displaced persons. According to the UN resettlement of IDPs has accelerated since October 2009, with the UN Refugee Agency (UNHCR) reporting that about 247,000 have either returned to their places of origin or to host families, leaving about 50,000 in three government camps. The IDPs remaining in the camps are allowed full freedom of movement. On May $28^{\text {th }}$, the president issued instructions to shut down the remaining camps within the next three months and complete the resettlement by August 2010. The UN's assessment is that there has been good progress in resettling IDPs but that further work is needed in improving their post-resettlement quality of life, including through reconstructing housing and ensuring opportunities to pursue livelihoods.

11. Program performance and changes to program design. All quantitative targets for end-March have been met (Letter of Intent, Table 1). The end-April structural benchmark on submission to parliament of a full-year 2010 budget consistent with program targets was not met and it has been changed to parliamentary approval of the budget by end-August 2010 . The submission of the Finance Company Act to parliament, an end-May structural benchmark, has been delayed, but the authorities expect submission before the Executive Board discussion of this review. The remaining three structural benchmarks - the approval of 
the pre-election budget, addressing the outstanding debts of the key state enterprises, and prudential guidelines for credit card companies have been met (Letter of Intent, Table 2).

\section{Policies ANd Discussion}

\section{A. Improving the Investment Climate}

12. Promoting private investment. The authorities have determined that in the postconflict environment and with elections over, and given the infrastructure needs of the country, now is the time to undertake a wholesale reform of the investment regime, including reforms aimed at reducing the currently high cost of doing business in Sri Lanka. To this end the government has established a high-level committee headed by the senior advisor to the president to identify laws and regulations obstructing investment. In addition, the government began liberalizing the trade regime and announced its intention to ratify a comprehensive economic partnership agreement with India in line with its development strategy. The Ministry of Economic Development, the BOI, and the Department of National Planning of the Ministry of Finance will be identifying in the coming months areas where there are large investment needs, and will begin formulating a national investment strategy. The finance ministry has also called on all ministries and government institutions to develop profiles of investment opportunities for foreign and domestic investments, public-private partnerships, and joint ventures with the government. A concession agreement with a foreign investor to build and operate a new container terminal at the port of Colombo is at an advanced stage of negotiation, while the authorities will also be calling for investment proposals for a new industrial zone next to the major southern port project under construction and a number of tourism zones.

13. Reforming the Board of Investment. To attract greater foreign direct investment, the government in early-June began implementing a new policy of broad-based reform of the Board's investment promotion regime which during the conflict years relied on large-scale tax holidays and duty exemptions to attract investment, sharply eroding the tax base and distorting the playing field for local industries. The planned reforms would aim to widen the revenue base and improve the investment climate by shifting emphasis away from tax concessions toward greater predictability for investors and increasing the ease of doing business, mainly by harmonizing the development activities of different ministries, public institutions, and other public and private agencies. On June 1 the authorities instructed the BOI, and the BOI agreed, to work with the relevant ministries to develop before end-August an investment

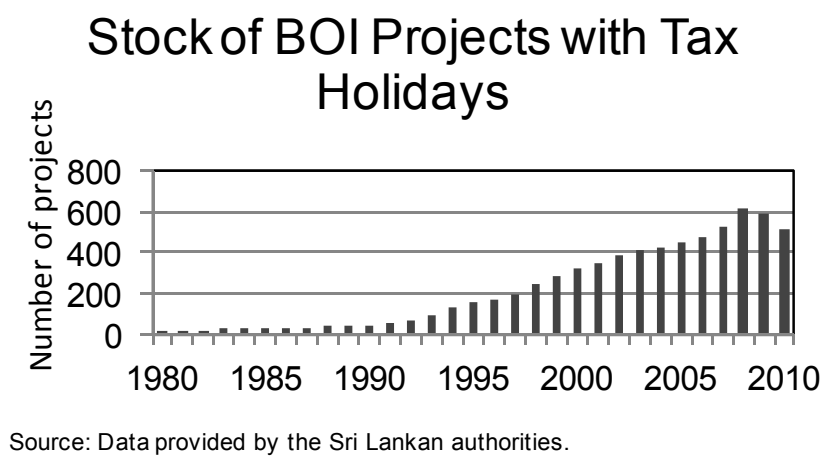


profile and a reasonable incentive package. This profile would aim to concentrate the BOI's efforts on only large investments for which impediments need to be clearly identified and addressed, rather than purely relying on tax concessions. The authorities intend to finalize the specific enabling legislation for these reforms as part of the 2011 budget (a new structural benchmark). Until then, as instructed by the authorities, the BOI will refrain from granting any further concessions until new regulations are finalized.

\section{B. Monetary and Exchange Rate Policy}

14. Monetary policy. The central bank has maintained its recent monetary easing as bank lending is slowly beginning to rebound and output remains below potential. Measures of inflation and broad monetary aggregates are also within a comfortable range. Staff and authorities agreed that in the postelection environment a rapid increase in credit growth is a possibility, and that there may be a need for the bank

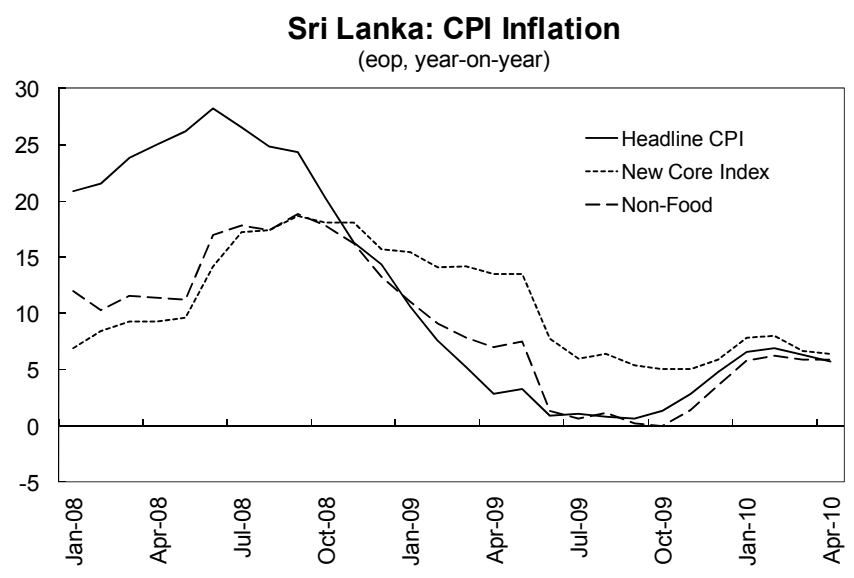
to tighten its policy stance in the months ahead.

15. Exchange rate policy. The central bank took advantage of the large capital inflows to rebuild reserves and prevented the strong foreign exchange inflows from appreciating the rate by intervening. However, an increase in import growth is likely, which would reduce the net supply of foreign exchange to the market. The authorities recognize this, reiterating their commitment to allow the exchange rate to move flexibly as needed to meet the program's reserve targets, and agreed that smoothing the path of intervention would be the right approach. Consistent with staff advice, the authorities have gradually introduced modest twoway exchange rate flexibility to signal to markets that exchange rate policy will not be anchored on a specific peg going forward. The daily intervention range is still quite narrow, however, and staff urged the central bank to consider further widening and to allow for greater two-way movements in the rate.

\section{Fiscal Policy}

16. The fiscal adjustment strategy. Although the government missed the program's 2009 deficit target and election-related delays have postponed tax reforms, the authorities expressed their commitment to a strategy in line with the program's original goals for reducing the deficit and bringing about fiscal and public debt sustainability. The authorities aim to bring this about through a combination of cuts in recurrent spending-while securing spending for ongoing resettlement and rehabilitation of the IDPs and protecting the most 
vulnerable in society — and tax reforms that simplify the system, expand the base, and result in a sustainable increase in revenue yield. Given that tax reforms are likely to take time to yield results, the authorities have based this year's budget on the assumption that revenue will increase by only by a small amount as a share of GDP, in line with the growth in taxed imports, with deficit reduction in 2010 driven by cuts in recurrent spending. At the same time, staff and the authorities agree that infrastructure spending is needed to boost medium term growth prospects and to address the needs of the war-torn north and east, and the fiscal strategy will need to allow room for the government's public investment program. As scope for further cuts in recurrent spending narrows, deficit reduction beyond this year will need to be realized mostly through improvements in revenue - the authorities target revenue to increase to $15^{1} \frac{1}{2}$ percent of GDP in 2011 from 143/4 percent assumed for this year, and 16 $1 / 2$ percent in 2012, bringing the ratio more in line with comparator countries (Box 1). If the tax reforms are carried out as described below, these targets would be achievable. This, together with the substantial expenditure cuts proposed for this year and modest additional cuts in 2011 and 2012, would allow the government to reach its budget deficit goal of 5 percent of GDP by 2012. The government's ultimate goal is to bring public debt down to 60 percent of GDP.

17. The 2010 budget. In line with this strategy the government submitted to parliament on June 8 a budget with full-year expenditure appropriations consistent with a 2010 deficit target of 8 percent of GDP. This compares with an original program target of 6 percent, or about $6^{3 / 4}$ to 7 percent after making adjustments for post-conflict reconstruction spending which had been anticipated at the time of the first review. Non-interest recurrent spendingled by cuts in subsidies and transfers and a $1 / 2$ percent of GDP cut in defense spendingwould be reduced by over 1 percent of GDP, to the level (excluding grant- and IDP resettlement-related spending) targeted in the original program, a key factor as part of the strategy of sustainable deficit reduction. The higher deficit target differs from the original program mainly comes from a more cautious revenue projection and higher than originally expected interest payments (although with real interest rates returning to historical levels in 2009 , the interest bill is expected to fall somewhat in 2010). Budgeted infrastructure spending is consistent with projections under the program's project monitoring framework. The budget is expected to be approved by parliament before end-July (a new structural benchmark). 
Sri Lanka: Central Government Operations, 2009-2010 (In percent of GDP)

\begin{tabular}{|c|c|c|c|c|}
\hline & \multicolumn{2}{|l|}{2009} & \multicolumn{2}{|l|}{2010} \\
\hline & Original Prog. & Prel. & Original Prog. & Budget \\
\hline Total revenue & 14.8 & 14.5 & 15.4 & 14.7 \\
\hline Grants $1 /$ & 0.2 & 0.5 & 0.2 & 0.4 \\
\hline Total expenditure and net lending & 21.9 & 24.9 & 21.5 & 23.2 \\
\hline Current expenditure & 16.5 & 18.2 & 15.8 & 16.9 \\
\hline Interest payments & 5.5 & 6.4 & 5.6 & 6.2 \\
\hline Other current & 11.1 & 11.8 & 10.2 & 10.7 \\
\hline Excl. grant-related & 10.9 & 11.3 & 10.1 & 10.2 \\
\hline Excl. grants and resettlement & 10.9 & 11.2 & 10.1 & 10.1 \\
\hline Civil service wages and salaries & 3.0 & 3.0 & 3.0 & 2.8 \\
\hline Other civilian goods and services & 0.8 & 1.0 & 0.8 & 0.9 \\
\hline Security related expenditure & 3.7 & 3.9 & 3.1 & 3.4 \\
\hline Subsidies and transfers & 3.6 & 3.9 & 3.3 & 3.6 \\
\hline Capital expenditure and net lending & 5.3 & 6.7 & 5.7 & 6.3 \\
\hline o/w: foreign financed & 2.2 & 3.1 & 3.1 & 3.6 \\
\hline Overall balance excluding reconstruction & $\ldots$ & -9.5 & -6.0 & -7.2 \\
\hline Overall balance & -7.0 & -9.9 & $\ldots$ & -8.0 \\
\hline \multicolumn{5}{|l|}{ Memorandum items: } \\
\hline Primary balance without capital spending & 3.9 & 3.2 & 5.4 & 4.5 \\
\hline Nominal GDP & 4913 & 4825 & 5905 & 5498 \\
\hline
\end{tabular}

Sources: Data provided by the Sri Lankan authorities; and Fund staff estimates.

$1 /$ The budget presentation now places grants above the line according to standard practice. Previously grants below the were classified line as a budget financing item. 
18. Debt sustainability. A path of

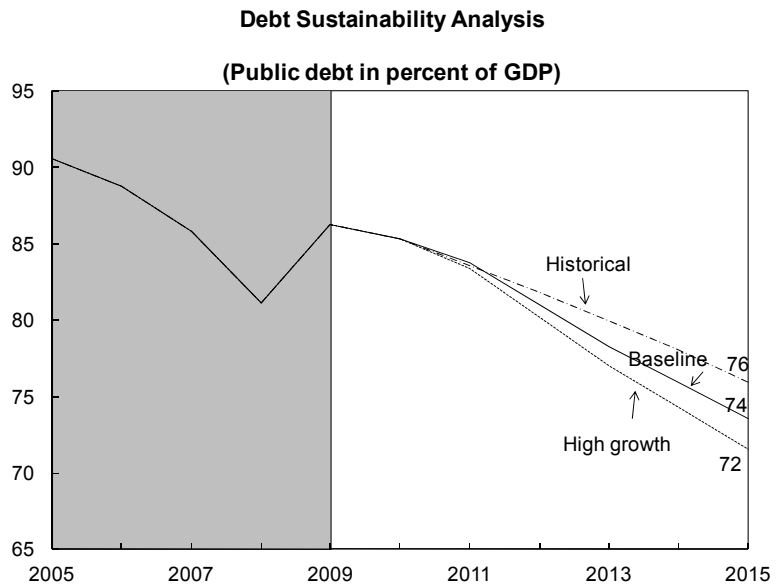

deficit reduction from 8 percent of GDP this year to $63 / 4$ percent in 2011 and ultimately 5 percent beginning in 2012 would be consistent with a declining path of the debt-to-GDP ratio, with the ratio falling from 86 percent currently to 74 percent by 2015 (compared to the program's original target of under 70 percent) even with a cautious output growth assumption (see Table below for the assumptions underlying the baseline projections). The reduction would be larger if the government's infrastructure spending program improves prospects for growth over the medium term.

\begin{tabular}{|c|c|c|c|c|c|c|c|c|}
\hline \multicolumn{9}{|c|}{$\begin{array}{l}\text { Public Sector Debt Sustainability Framework, 2005-2012 } \\
\text { (In percent of GDP, unless otherwise indicated) }\end{array}$} \\
\hline & \multicolumn{5}{|c|}{ Actual } & \multicolumn{3}{|c|}{ Projections } \\
\hline & 2005 & 2006 & 2007 & 2008 & 2009 & 2010 & 2011 & 2012 \\
\hline Baseline: Public sector debt & 90.6 & 88.7 & 85.8 & 81.1 & 86.2 & 85.3 & 83.8 & 81.0 \\
\hline \multicolumn{9}{|c|}{ Key Macroeconomic and Fiscal Assumptions Underlying Baseline } \\
\hline Real GDP growth (in percent) & 6.2 & 7.7 & 6.8 & 6.0 & 3.5 & 6.5 & 6.5 & 6.5 \\
\hline Average nominal interest rate on public debt (in percent) $1 /$ & 5.6 & 6.8 & 7.0 & 6.9 & 8.7 & 8.1 & 7.6 & 7.3 \\
\hline Average real interest rate (in percent) $2 /$ & -4.8 & -4.5 & -7.0 & -9.4 & 3.0 & 1.1 & 1.2 & 1.6 \\
\hline Primary deficit & 3.5 & 2.9 & 2.6 & 2.9 & 3.5 & 1.9 & 1.0 & -0.4 \\
\hline Overall deficit & 7.2 & 7.0 & 6.9 & 7.0 & 9.9 & 8.0 & 6.8 & 5.0 \\
\hline
\end{tabular}

19. Tax reform. The work of the Presidential Tax Commission is nearing completionthe commission submitted its specific recommendations to the president in May, with the final report expected by end-July (Box 1). Informed by the commission's work, the government is launching key reforms now, followed by further reforms during the remaining months of 2010 and legislative changes as part of the 2011 budget:

- $\quad$ Trade and excise taxes. On June 1 the government began implementing an ambitious reform of the trade and excise tax regime, in line with the tax commission's recommendations, including a reduction in the scope of exemptions, a simplification of the import tariff rate structure, an elimination of surcharges and extra-tariff duties, and a reduction in prohibitively high tariffs on important revenue-yielding items such 


\section{Box 1. Background to the Presidential Tax Commission}

Sri Lanka's revenue-to-GDP ratio has been on a declining trend since the 1990s. Reversing the erosion of revenues is critical to restore health to public finances and to reach the steady-state fiscal deficit target of 5 percent as stipulated by the Fiscal Management Responsibility Act.

Sri Lanka: Revenue Performance, 1995-2009

\begin{tabular}{lrrrr}
\multicolumn{5}{c}{ (In percent of GDP) } \\
\hline Total Revenue & 1995 & 2000 & 2005 & 2009 \\
Tax revenue & 19.7 & 16.2 & 15.5 & 14.5 \\
Non-tax & 17.2 & 14.0 & 13.7 & 12.8 \\
\hline
\end{tabular}

Sri Lanka's current revenue ratio of $14 \frac{1}{2}$ percent of GDP is low compared with other Asian emerging market countries. Using this set of comparators, Sri Lanka's central government revenue is unusually dependent on taxes on goods and services, driven in particular by VAT and excise tax collections. The revenue yield of direct taxes in Sri Lanka is low, reflecting the narrow base, despite relatively high rates by emerging market standards. Corporate income tax collection is lagging mainly owing to the narrow base, which has been eroded by widespread exemptions under the BOI regime and tax evasion. Personal income tax collections are also low, though comparable to other Asian emerging market countries, reflecting a narrow base due to exemptions and low compliance. On the trade side, multiple taxes on imports, which have been adopted in recent years for revenue enhancement, have created a complex and distortionary trade regime. The revenue productivity of VAT is below average in Sri Lanka owing to a relatively narrow base from exemptions and low compliance. Against this background, a Presidential Tax Commission was appointed in June 2009 to study why tax revenue-to-GDP has declined and what measures - including base broadening measures and simplification of the highly complex tax regime - are needed to achieve a revenue-to-GDP ratio comparable to other emerging market countries.

\section{Central Government Revenue as \% of GDP}

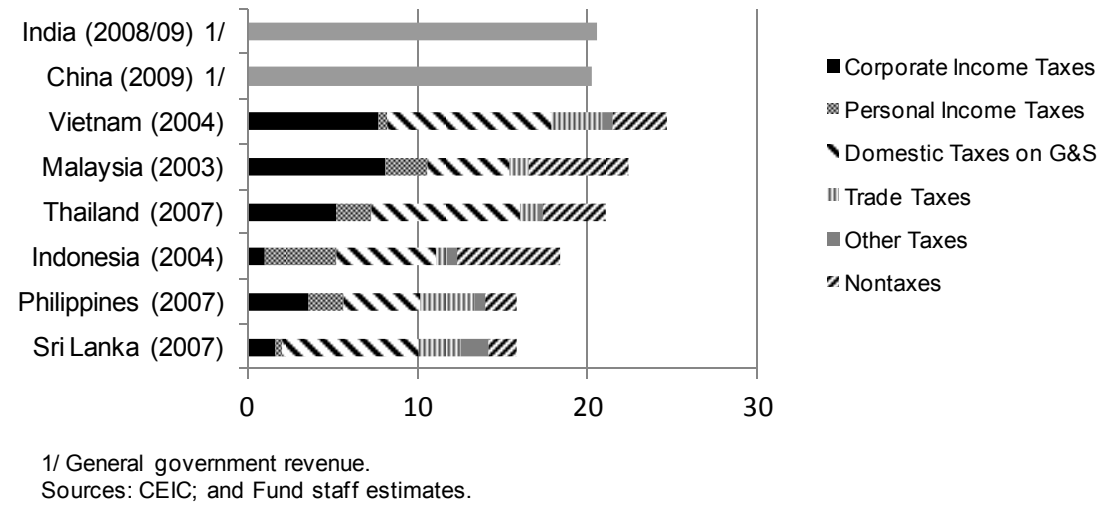




\section{Box 1. Recommendations of the Presidential Tax Commission (concluded)}

Ahead of the final report to be published in the summer of 2010, the Tax Commission has submitted to the government its specific recommendations. The Commission's recommendations complement the ongoing reform of investment incentives under the BOI, with the aim of reaching a revenue ratio of 20 percent of GDP by 2016.

\begin{tabular}{|c|c|c|c|c|}
\hline & \multicolumn{3}{|c|}{ Performance of Value-Added Tax (VAT) } & \multirow[b]{2}{*}{$\begin{array}{c}\text { Applicable } \\
\text { Year }\end{array}$} \\
\hline & $\begin{array}{l}\text { Standard } \\
\text { Rate }\end{array}$ & $\begin{array}{l}\text { VAT Revenue } \\
\text { as } \% \text { of GDP }\end{array}$ & Productivity & \\
\hline China & 17 & 5.8 & 33.9 & 2006 \\
\hline India & 12.5 & $\cdots$ & & \\
\hline Indonesia & 10 & 3.5 & 35.3 & 2006 \\
\hline Philippines & 12 & 4.3 & 35.8 & 2006 \\
\hline Thailand & 7 & 3.9 & 56.0 & 2006 \\
\hline Vietnam & 10 & 5.6 & 56.2 & 2006 \\
\hline Sri Lanka & 15 & 4.7 & 31.5 & 2006 \\
\hline
\end{tabular}

as motor vehicles. ${ }^{1}$ This will be followed by further increases in some excise taxes and the elimination of duty concessions on some key commodities. This represents a significant trade liberalization, and could result in higher imports and help boost output growth. The net revenue yield of lower tariffs and a rebound in imports of high tax-yielding item is uncertain, and depends on difficult-to-estimate demand elasticities. But based on historic figures, these measures could ultimately yield an increase in annual tax revenue of $1 / 4$ to $1 / 2$ percent of GDP.

- $\quad$ Reducing tax concessions. One key element of the BOI reforms described above will be to reduce lost tax revenue from various concessions including ad hoc tax holidays on VAT and corporate income taxes and duty exemptions. As tax concessions offered in the past under the BOI regime have been the largest contributor to Sri Lanka's eroded tax base, limiting new concessions and reforming the BOI would be the most significant base-broadening tax measure as part of the government's tax reform strategy - this measure could ultimately yield as much as $1 \frac{1}{2}$ percent of GDP in annual revenue, depending on how narrow the new concession regime is defined.

\footnotetext{
${ }^{1}$ In designing these reforms, the authorities have been mindful of the WTO tariff commitments.
} 
Since a sizeable portion of existing concessions are set to expire over the next two years (with nearly all expiring by 2015), and more importantly since all new investments will be fully taxed until the new regime is in place, these reforms could have a significant near-term revenue impact.

- Income taxes and VAT. The authorities are committed to taking steps to rationalize the VAT rates, and broaden the VAT and income tax bases (as noted in paragraph 7 of the LOI). These changes will be introduced as part of the 2011 budget law (included in the new structural benchmark of submission of the budget to parliament by end-November). Base broadening could allow for a reduction in rates-which is expected to increase compliance - depending on the revenue yield of other tax reforms and minding the need to meet the government's overall tax revenue goals. The authorities are currently considering a menu of options to achieve these results, and will take into consideration the recommendations of the Tax Commission. Staff will discuss the specifics of the government's planned reforms during the next review.

\section{State Enterprise Reform}

20. Reforming public enterprises. The government has put in place measures aimed at improving the operations of public enterprises. In May the government began replacing the heads of all public enterprises with private sector managers who have operational experience, with the mandate to run the enterprises on a commercial basis and improve profitability. At the same time the finance ministry issued a directive to profit-making state enterprise instructing them to pay dividends to the budget. This process is already underway, and is expected to yield around $1 / 4$ percent of GDP in annual non-tax revenue.

21. State-owned enterprises. The financial performance of the Ceylon Petroleum Company (CPC) and the Ceylon Electricity Board (CEB) was better than expected in 2009 with a deficit just short of $1 / 2$ percent of GDP against an indicative target of $3 / 4$ percent. The CPC limited its losses as international market prices for petroleum products remained below domestic retail prices. The CEB's losses were less than expected owing to favorable rainfall which allowed a shift to relatively cheap hydro power from more expensive thermal electricity generation. For 2010 , the projected losses remain at $1 / 2$ percent of GDP in line with the program target. Going forward, new management with a mandate to operate more commercially is expected to improve these enterprises' performance, and intends to restructure the outstanding non-performing debt of the CPC and CEB. Electricity is costly in Sri Lanka, and the Power and Energy Ministry has announced its intent to rationalize electricity prices beginning in early-2011. The government's program to put in place longerterm measures to reduce generation costs, drawing on assistance from the ADB, remains on track. 


\section{E. Financial Sector}

22. Financial sector reform. The program's financial sector reform agenda is on track with the issuance of prudential regulations on credit card companies and payment service providers (a structural benchmark) and the expected submission to parliament of the amendments to the Finance Companies Act (a structural benchmark), both of which address regulatory gaps that led to stresses in the financial sector in 2008-09. The Central Bank is also amending loan classification standards to temporarily facilitate the workout of the legacy of higher non-performing loans due to the global crisis. However, the conditions set forth to encourage a workout of problem loans falls below international best practice and staff suggested that a well-defined framework for corporate restructuring would be preferable to ensure that the most viable enterprises are both financial and operationally resurrected. The financial sector reform agenda has also been broadened to include the introduction of a deposit insurance scheme, regulation of pension funds, and steps to deepen capital markets (see Letter of Intent).

\section{Program Design AND Risks}

23. Program extension and rephasing. The authorities acknowledge that the implementation of the key fiscal reforms has been delayed by one year. With the war and the elections over, however, they recognize that they now face a unique opportunity to press ahead with a bold reform agenda that incorporates all the elements of the original program design. They believe that the SBA program will be important for strengthening the government's efforts toward meeting its policy goals going forward. In line with this, and to support the wide range of policy reforms that the government is planning to undertake this year and next, the authorities have requested a one-year extension of the program through end-2011. They have requested that the remaining undisbursed funds be rephased in line with this extension (Table 7).

24. Program design. To reflect Sri Lanka's graduation from PRGT eligibility, the Technical Memorandum of Understanding (Attachment II) and the table of quantitative performance criteria have been revised to exclude the ceiling on the contracting of nonconcessional external debt.

25. Risks. The government's policy proposals, if implemented, would address past slippages and put the program back on track. There are risks however:

- The government has taken significant steps already to reform the trade tax regime, suspend granting of new BOI tax concessions, and to reform public enterprises, and has indicated positive intentions for further reforms. But some of these reforms will not be fully articulated until late-2010 when the 2011 budget is prepared, and implemented only in 2011. The government's statement of intent is encouraging, but 
there can be no guarantee that the reforms will ultimately be implemented as currently intended.

- $\quad$ The revenue yield from the current and planned tax reforms is far from certain, with both positive and negative risks. In this regard, the relatively cautious revenue assumption the authorities are using on which to base the 2010 budget is a welcome sign that the authorities are keenly aware of these risks.

- $\quad$ As in 2009, there is the risk that the government would exceed the spending limits spelled out in the budget. The end of the war and elections delivering the government a solid majority and a long horizon could, however, strengthen the government's ability to carry out its commitments on deficit reduction in 2010.

- A further intensification of the existing international financial turmoil could trigger a quick capital outflow given the some $\$ 1 \frac{1}{2}$ billion in Sri Lanka's short-term liabilities to external investors. A sharp increase in imports from the recent trade liberalization could also put pressure on the balance of payments. Although Sri Lanka has an adequate reserve buffer against these events, they would still have a negative impact on investor confidence. Access to Fund disbursements through future adherence to the program's targets should help mitigate these risks.

\section{Staff Assessment}

26. Overview. Although the immediate risk of a balance of payments crisis has receded and much progress has been made in rebuilding reserves and advancing financial sector reform, 2009 was a lost year in terms of deficit reduction and tax reform. The war is over and elections are now past, and since then the government has given significant positive signals that it will exploit the window of opportunity offered by the current stable environment to launch reforms that improve private sector growth, attract investment, and address the fiscal vulnerabilities. The authorities have proposed a solid post-election policy agenda that would address past slippages and, if implemented, would result in significant progress toward meeting the program's original goals, including fundamental and sustainable budget deficit reduction.

27. Monetary policy and exchange rate policy. The central bank's policy stance so far has been appropriate, although there may be a need to tighten its stance if credit picks up sharply in the coming months. The exchange rate will need to show more flexibility if rapid growth of imports begins putting pressure on the balance of payments.

28. Reforming the Board of Investment. For 30 years, the investment promotion regime has relied primarily on wide-spread, often ad hoc tax concessions that have significantly eroded the tax base and distorted the playing field for domestic investors. Reforming this regime is fundamental to address these weaknesses. By undertaking these reforms, the government has demonstrated a recognition that in the post-war economy a 
stable and simple business environment is what is critical for attracting investment, and that large tax concessions are no longer necessary.

29. Fiscal policy. Although the budget outturn for 2009 and election-related delays in fiscal reforms call for some recalibration of the program, the program's original goals of fundamental and sustainable deficit reduction remain unchanged. In line with this, the government's proposed 2010 budget would be a first step toward meeting these goals by incorporating significant cuts in recurrent spending and allowing room for much needed public infrastructure investment. Beyond 2010, further deficit reduction will need to be driven primarily through increases in revenue to bring the ratio to GDP closer to key comparator countries. This adjustment will also need to preserve social spending and meet the need to resettle the remaining internally displaced persons and rehabilitate the war-torn north and east.

30. Tax reform. The government has already taken significant actions as part of their effort to simplify the complicated and inefficient tax system, address distortions, broaden the tax base, and ultimately bring about a sustainable increase in revenue. The reform of trade and excise taxes not only corrects a complicated and difficult to enforce regime which had been built up over the past decade, but will also add much-needed predictability to the tax system. By halting new tax concessions under the Board of Investment regime, the authorities have taken the first step in reversing the most significant source of tax base erosion. Further steps are needed however to put in place legislative changes to permanently reform tax concessions under the new regime, and to simplify and broaden the bases for the VAT and income taxes.

31. Financial sector reforms. The government's actions so far have gone a long way toward addressing past weaknesses in the financial sector, and have demonstrated the authorities' commitment take the necessary steps to strengthen regulation and its legal framework. This work will continue in important areas, including putting in place a deposit insurance system and establishing a regulatory framework for pensions.

32. Risks. The government has yet to carry out its commitment to deficit reduction, and actions on tax reforms have been delayed by one year. The fiscal performance so far this year and the recently-enacted tax reforms are first steps in helping to build the government's credibility toward meeting its goals, but if this is to continue, it will be important that the government meets all of its deficit targets going forward, and carries out its commitment to enact the promised additional tax reform measures in the 2011 budget. The revenue yield from the tax reform measures is far from certain, and the government will need to be prepared to adjust tax rates if needed to meet its revenue targets.

33. Despite the poor 2009 fiscal performance, the government's 2010 budget proposal, if carried out, would go a long way to address past fiscal slippages. The government's significant up-front actions on tax reform are an important signal that the government has the 
will to bring its fiscal program back on track. Financial sector reform has continued in line with the program, and has gone far to address regulatory weaknesses. On this basis the staff recommends the approval of the Second and Third Reviews, and supports the authorities' request for an extension and rephasing of the program. 
Figure 1. Sri Lanka: Economic and Program Performance

The economy is likely to show strong growth this year.

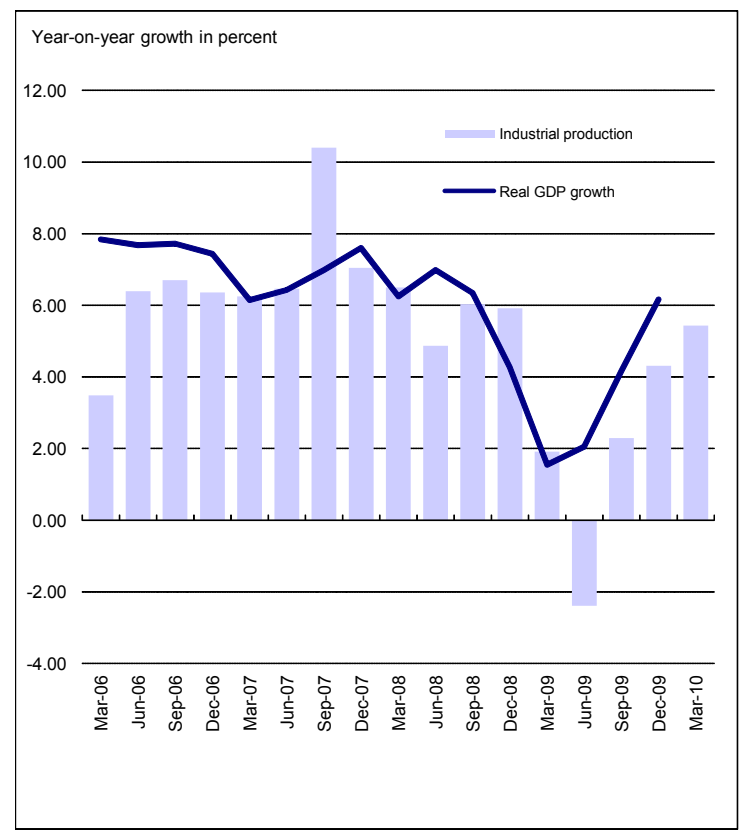

Sovereign risk spreads remain relatively low and capital inflows to domestic government bonds continue..

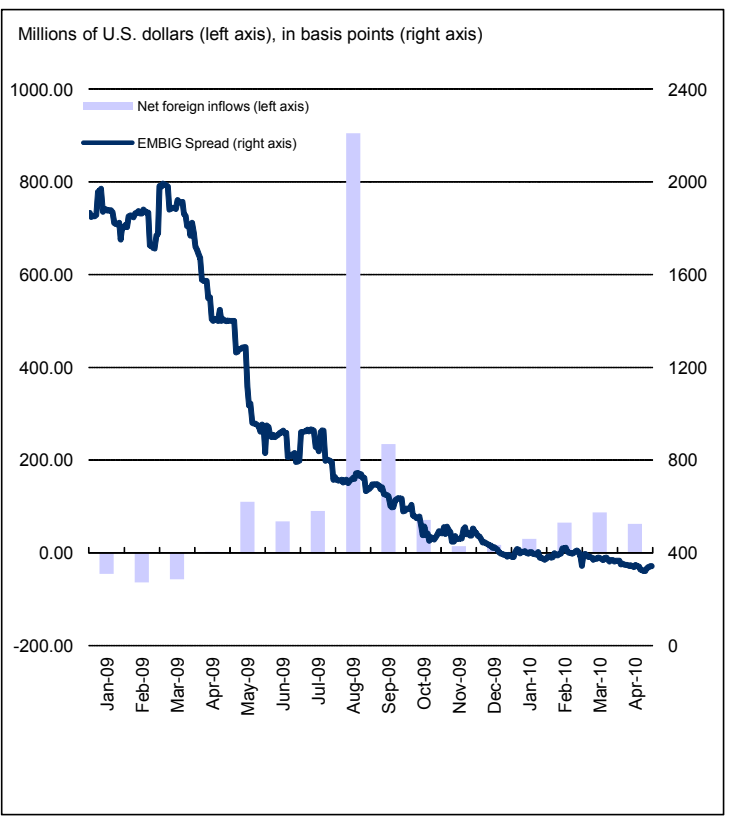

Inflation remains subdued, and the central bank keeps the key policy rates low.

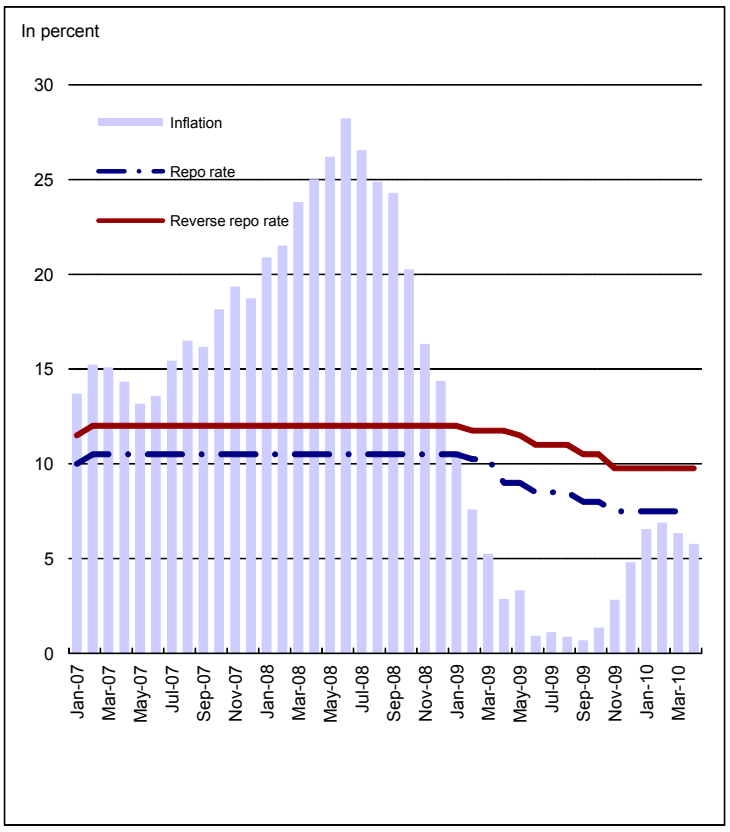

...putting some upward pressure on the exchange rate.

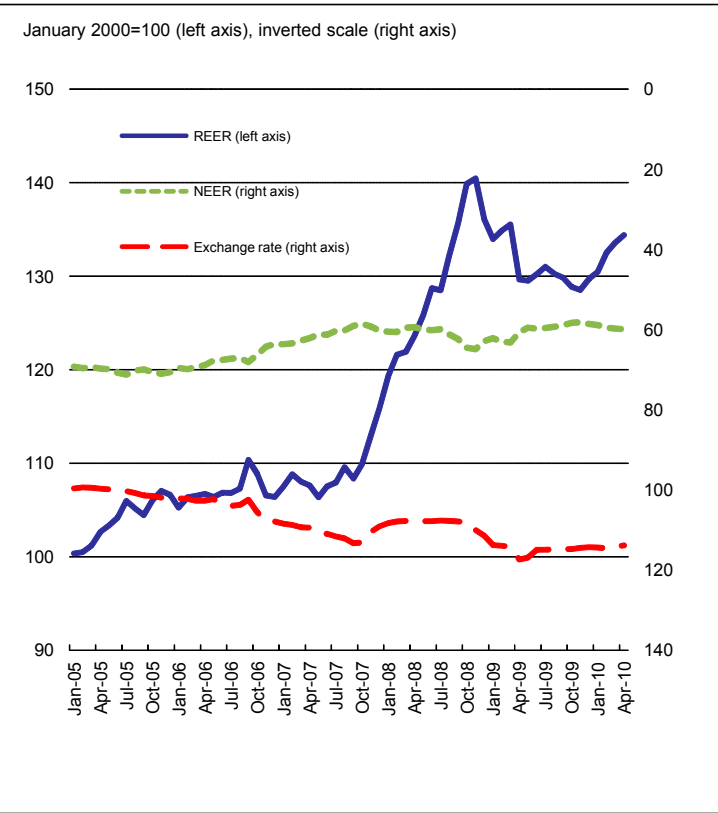

Sources: CEIC Data Company Ltd.; Bloomberg LP; and Fund staff estimates. 
Figure 2. Fiscal and Monetary Developments

The fiscal deficit increased on the back of declining revenue...

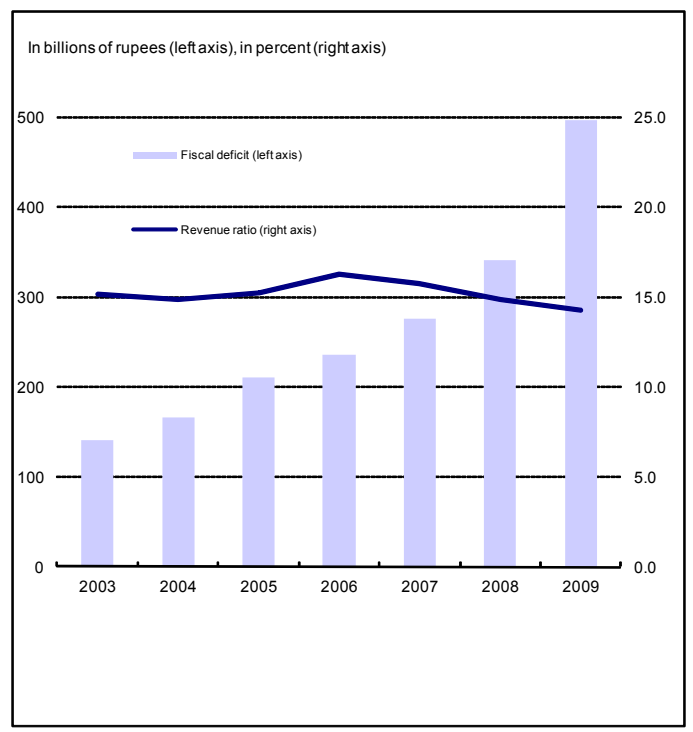

Domestic liquidity conditions have loosened.

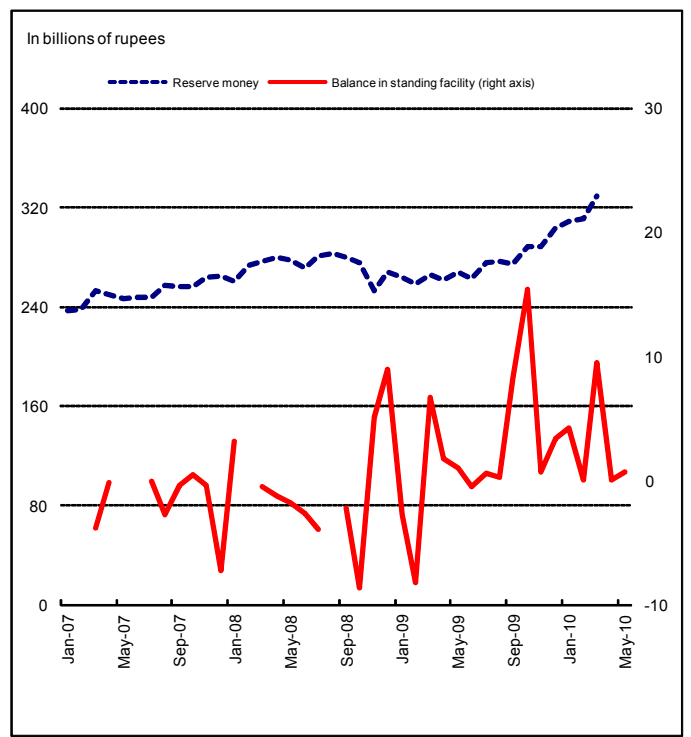

...although there are signs that revenue is improving as the economy recovers.

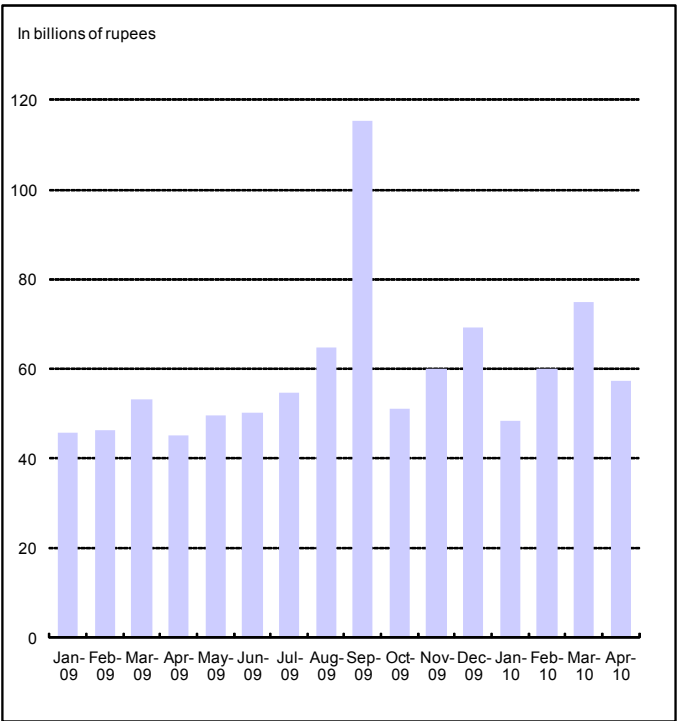

Private sector growth remains low although there are signs that credit demand is picking up.

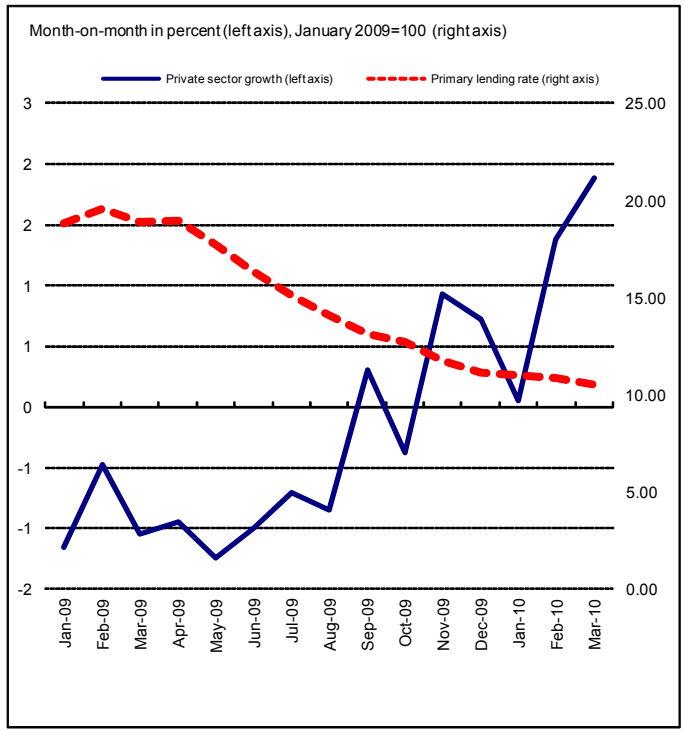

Sources: Central Bank of Sri Lanka; CEIC Data Company Ltd.; Bloomberg LP; and Fund staff estimates. 
Figure 3. External and Financial Developments

The recovery has led to an expansion in imports and an increase in the trade deficit..

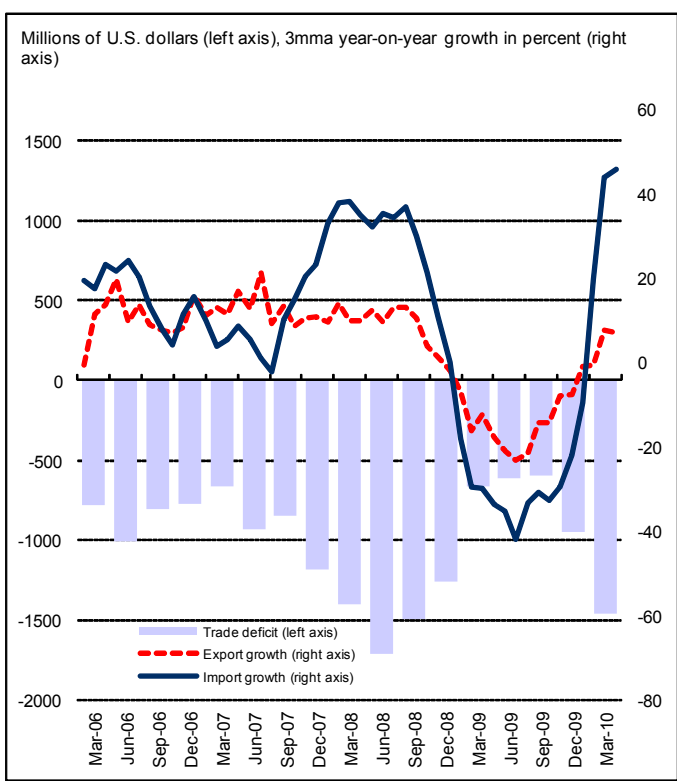

The stock market has reached all-time highs on the back of rising confidence following the end of the war..

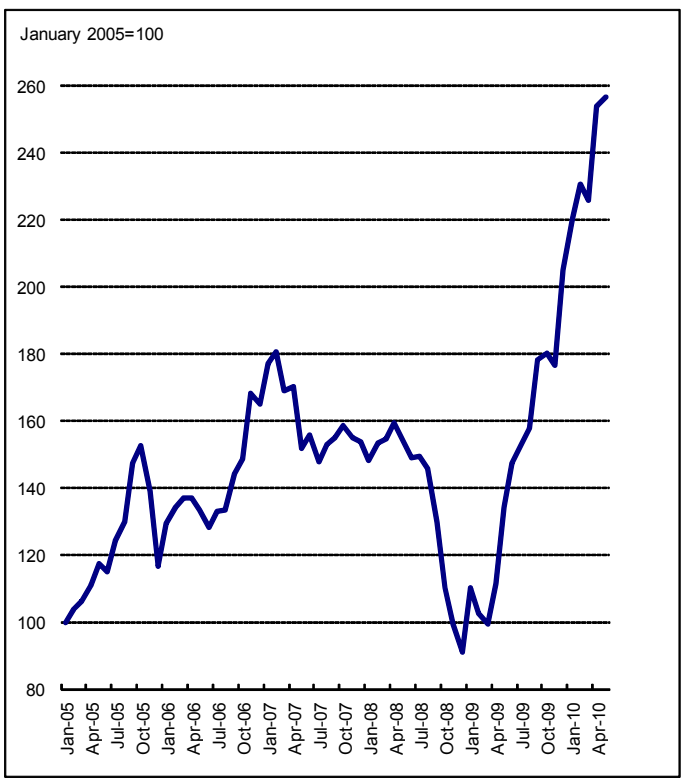

while the exchange rate has remained relatively stable with only modest Central Bank intervention this year.

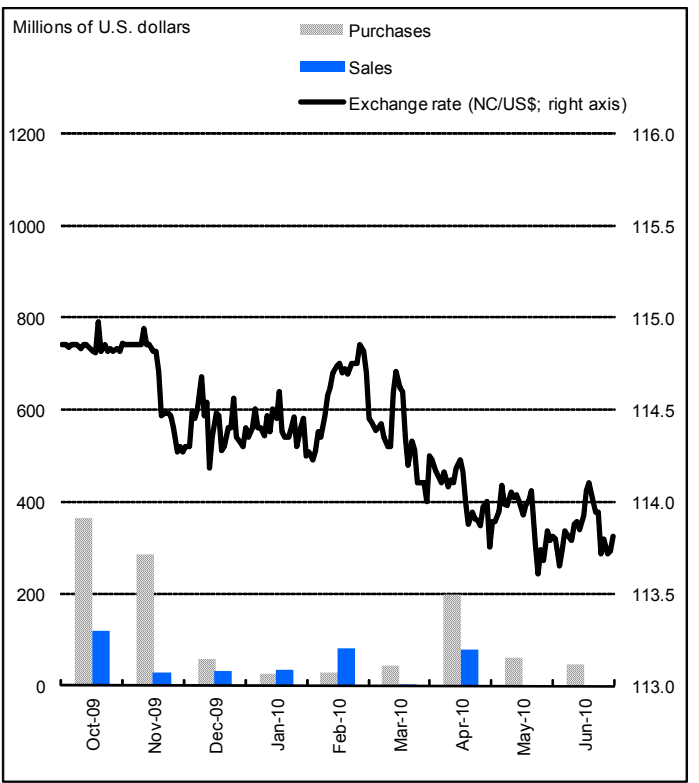

...while NPLs of the banking system are starting to decline from their peak.

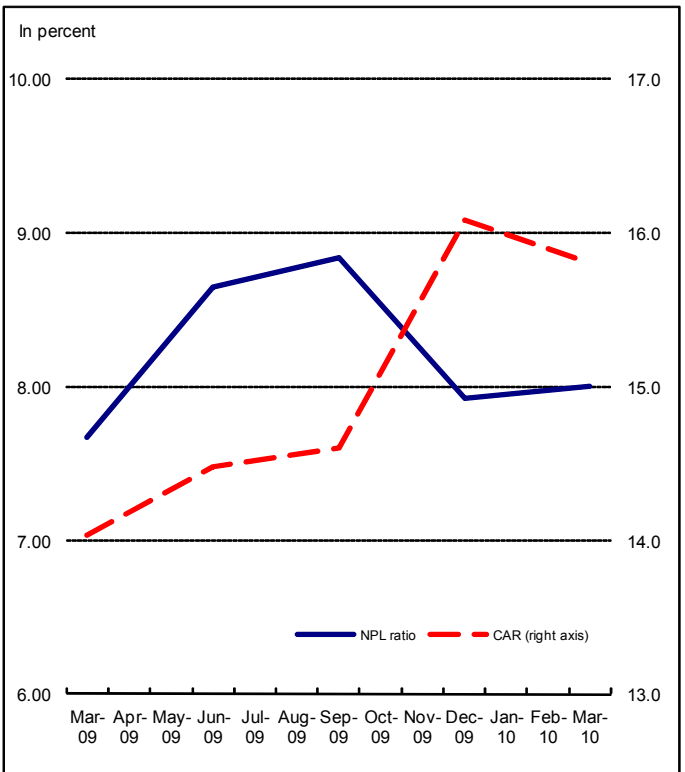

Sources: Central Bank of Sri Lanka; CEIC Data Company Ltd.; and Fund staff estimates. 
Table 1. Sri Lanka: Selected Economic Indicators, 2008-2012

Main exports (percent of total, 2008): garment (43), tea (16)

GDP per capita (2008, est.): US\$1,972

Unemployment rate (2008): 5.4 percent

Poverty rate (2007, incidence): 15.2 percent

FDI (2008, est.): \$691 million

Public debt (2008): 81.1 percent of GDP

\begin{tabular}{|c|c|c|c|c|c|c|c|}
\hline & \multirow[t]{2}{*}{2008} & \multicolumn{2}{|c|}{2009} & \multicolumn{2}{|c|}{2010} & \multirow{2}{*}{$\begin{array}{l}2011 \\
\text { Proj. }\end{array}$} & \multirow{2}{*}{$\begin{array}{r}2012 \\
\text { Proj. }\end{array}$} \\
\hline & & 1st Review & Prel. & 1st Review & Rev. Prog. & & \\
\hline \multicolumn{8}{|l|}{ GDP and inflation (in percent) } \\
\hline Real GDP growth & 6.0 & 3.0 & 3.5 & 5.0 & 6.5 & 6.5 & 6.5 \\
\hline Inflation (average) & 22.6 & 4.0 & 3.4 & 11.2 & 7.0 & 6.5 & 5.8 \\
\hline Inflation (end-of-period) & 14.4 & 6.9 & 4.8 & 9.5 & 7.2 & 5.8 & 5.8 \\
\hline \multicolumn{8}{|l|}{ Public finances (in percent of GDP) } \\
\hline Revenue 1/ & 14.9 & 15.2 & 15.0 & 15.4 & 15.2 & 15.9 & 16.9 \\
\hline Expenditure & 22.6 & 22.3 & 24.9 & 21.5 & 23.2 & 22.6 & 21.9 \\
\hline Central government balance $1 /$ & -7.7 & -7.0 & -9.9 & -6.0 & -8.0 & -6.8 & -5.0 \\
\hline Consolidated government balance $1 /$ & -8.8 & -7.7 & -10.3 & -6.6 & -8.6 & -6.6 & -5.0 \\
\hline Central government domestic financing & 7.1 & 3.8 & 5.1 & 4.2 & 6.2 & 3.9 & 3.0 \\
\hline Government debt (domestic and external) & 81.1 & 81.4 & 86.2 & 84.1 & 85.3 & 83.8 & 81.0 \\
\hline \multicolumn{8}{|l|}{ Money and credit (percent change, end of period) } \\
\hline Reserve money & 1.5 & 15.5 & 13.1 & 14.6 & 18.6 & 13.9 & 13.8 \\
\hline Broad money & 8.5 & 17.5 & 18.6 & 16.7 & 18.8 & 15.6 & 14.9 \\
\hline Domestic credit & 18.0 & 4.4 & 3.4 & 14.7 & 15.4 & 16.9 & 14.6 \\
\hline Private sector credit & 7.9 & 3.2 & -6.5 & 17.4 & 14.6 & 23.2 & 20.2 \\
\hline Public sector credit & 46.2 & 7.1 & 23.7 & 9.2 & 16.8 & 7.2 & 4.8 \\
\hline \multicolumn{8}{|l|}{ Balance of payments (in millions of U.S. dollars) } \\
\hline Exports & 8,110 & 7,237 & 7,085 & 7,800 & 7,912 & 8,355 & 8,886 \\
\hline Imports & 14,091 & 10,209 & 10,206 & 11,633 & 13,193 & 13,884 & 14,587 \\
\hline Current account balance & $-3,886$ & -130 & -214 & -987 & $-2,444$ & $-2,486$ & $-2,448$ \\
\hline Current account balance (in percent of GDP) & -9.8 & -0.3 & -0.5 & -2.3 & -5.2 & -4.9 & -4.5 \\
\hline Export value growth (percent) & 6.2 & -11.1 & -12.6 & 7.8 & 11.7 & 5.6 & 6.3 \\
\hline Import value growth (percent) & 24.7 & -27.1 & -27.6 & 13.9 & 29.3 & 5.2 & 5.1 \\
\hline \multicolumn{8}{|l|}{ Gross official reserves (end of period) 2/ } \\
\hline In millions of U.S. dollars & 1,580 & 4,849 & 4,925 & 6,244 & 5,564 & 6,428 & 6,889 \\
\hline In months of imports & 1.6 & 4.4 & 4.0 & 5.4 & 4.3 & 4.7 & 4.8 \\
\hline As a percent of short-term debt & 29 & 87 & 83 & 107 & 88 & 94 & 105 \\
\hline \multicolumn{8}{|l|}{ External debt (public and private) } \\
\hline In billions of U.S. dollars & 17.6 & 18.8 & 19.2 & 20.5 & 21.6 & 23.3 & 24.7 \\
\hline As a percent of GDP & 44.4 & 44.5 & 45.6 & 48.9 & 46.1 & 46.0 & 45.3 \\
\hline \multicolumn{8}{|l|}{ Total stock of public dollar commercial debt 3/ } \\
\hline In millions of U.S. dollars & 2,658 & 3979 & 4,423 & 3,690 & 4,228 & 4,196 & 3,916 \\
\hline As a percent of GDP & 6.7 & 9.4 & 10.5 & 8.8 & 9.0 & 8.3 & 7.2 \\
\hline As percent of gross official reserves & 168 & 82 & 90 & 59 & 71 & 67 & 60 \\
\hline
\end{tabular}

Sources: Data provided by the Sri Lankan authorities; CEIC Data Company Ltd.; Bloomberg LP.; and Fund staff estimates and projections.

$1 /$ The budget presentation now places grants above the line according to standard practice. Previously grants were classified below the line as a budget deficit financing item. The consolidated government balance includes the Ceylon Electricity Board and the Ceylon Petroleum Corporation.

2/ Excluding central bank Asian Clearing Union (ACU) balances.

3/ Staff estimates based on total stock outstanding of foreign exchange commercial debt plus nonresident purchase of rupee-denominated treasury

bonds. 
Table 2. Sri Lanka: Summary of Central Government Operations, 2008-2012

(In percent of GDP, unless otherwise indicated)

\begin{tabular}{|c|c|c|c|c|c|c|c|}
\hline & \multirow[t]{2}{*}{2008} & \multicolumn{2}{|l|}{2009} & \multicolumn{2}{|c|}{2010} & \multirow{2}{*}{$\begin{array}{l}2011 \\
\text { Proj. }\end{array}$} & \multirow{2}{*}{$\begin{array}{l}2012 \\
\text { Proj. }\end{array}$} \\
\hline & & 1st Review & Prel. & 1st Review & Rev. Prog. & & \\
\hline Total revenue & 14.9 & 14.8 & 14.5 & 14.9 & 14.7 & 15.5 & 16.5 \\
\hline Tax revenue & 13.3 & 13.3 & 12.8 & $\ldots$ & 13.1 & 13.7 & 14.5 \\
\hline Income taxes & 2.9 & 3.2 & 2.9 & $\ldots$ & 2.9 & 3.1 & 3.3 \\
\hline Value added tax/GST & 4.6 & 3.7 & 3.6 & $\ldots$ & 3.8 & 4.0 & 4.3 \\
\hline Excise taxes & 2.3 & 2.2 & 2.0 & $\ldots$ & 2.1 & 2.1 & 2.3 \\
\hline Taxes on international trade & 1.8 & 1.9 & 2.0 & $\ldots$ & 2.0 & 2.1 & 2.2 \\
\hline Other & 1.7 & 2.5 & 2.3 & $\ldots$ & 2.4 & 2.4 & 2.5 \\
\hline Nontax revenue & 1.6 & 1.4 & 1.7 & $\ldots$ & 1.6 & 1.8 & 2.0 \\
\hline Grants 1/ & $\ldots$ & 0.5 & 0.5 & 0.5 & 0.4 & 0.4 & 0.4 \\
\hline Total expenditure and net lending & 22.6 & 22.3 & 24.9 & 21.5 & 23.2 & 22.6 & 21.9 \\
\hline Current expenditure & 16.9 & 17.2 & 18.2 & 16.0 & 16.9 & 16.3 & 15.9 \\
\hline Civil service wages and salaries & 3.2 & 3.0 & 3.0 & $\ldots$ & 2.8 & 3.0 & 3.0 \\
\hline Other civilian goods and services & 1.1 & 0.8 & 1.0 & $\ldots$ & 0.9 & 0.9 & 0.9 \\
\hline Security related expenditure & 3.9 & 3.8 & 3.9 & $\ldots$ & 3.4 & 3.2 & 3.0 \\
\hline Subsidies and transfers & 3.9 & 3.5 & 3.9 & $\ldots$ & 3.6 & 3.6 & 3.6 \\
\hline Interest payments & 4.8 & 6.1 & 6.4 & $\ldots$ & 6.2 & 5.7 & 5.4 \\
\hline Foreign & 0.5 & 0.7 & 0.7 & $\ldots$ & 0.7 & 1.1 & 1.2 \\
\hline Commercial & 0.2 & 0.0 & 0.1 & $\ldots$ & 0.1 & 0.1 & 0.2 \\
\hline Domestic & 4.1 & 5.5 & 5.6 & $\ldots$ & 5.4 & 4.5 & 4.1 \\
\hline Capital expenditure and net lending & 5.7 & 5.1 & 6.7 & 5.5 & 6.3 & 6.3 & 6.0 \\
\hline Overall balance of central Government $1 /$ & -7.7 & -7.0 & -9.9 & -6.0 & -8.0 & -6.8 & -5.0 \\
\hline Financing & 7.7 & 7.0 & 9.9 & 6.0 & 8.0 & 6.8 & 5.0 \\
\hline Net external financing $2 /$ & 0.6 & 3.3 & 4.8 & 1.8 & 1.8 & 2.8 & 2.0 \\
\hline Net domestic financing & 7.1 & 3.8 & 5.1 & 4.2 & 6.2 & 3.9 & 3.0 \\
\hline Privatization & 0.0 & 0.0 & 0.0 & 0.0 & 0.0 & 0.0 & 0.0 \\
\hline \multicolumn{8}{|l|}{ Memorandum items: } \\
\hline Primary balance (excluding grants) & -2.9 & -1.4 & -4.0 & $\ldots$ & -2.3 & -1.5 & 0.0 \\
\hline Total public debt & 81.1 & 81.4 & 86.2 & 84.1 & 85.3 & 83.8 & 81.0 \\
\hline Domestic debt & 48.3 & 45.8 & 49.8 & 44.4 & 49.6 & 47.9 & 45.2 \\
\hline Foreign debt & 32.8 & 35.6 & 36.5 & 39.7 & 35.7 & 35.9 & 35.8 \\
\hline
\end{tabular}

Sources: Data provided by the Sri Lankan authorities; and Fund staff estimates. 
Table 3. Sri Lanka: Monetary Accounts, 2008-2012

\begin{tabular}{|c|c|c|c|c|c|c|c|}
\hline & \multirow[t]{2}{*}{2008} & \multicolumn{2}{|c|}{2009} & \multicolumn{2}{|c|}{2010} & \multirow{2}{*}{$\frac{2011}{\text { Proj. }}$} & \multirow{2}{*}{$\begin{array}{l}2012 \\
\text { Proj. }\end{array}$} \\
\hline & & 1st Review & Prel. & 1st Review & Rev. Prog. & & \\
\hline Monetary authorities & \multicolumn{5}{|c|}{ (Stocks, in billions of Sri Lankan rupees) } & & \\
\hline Net foreign assets & 148 & 421 & 412 & 531 & 486 & 514 & 581 \\
\hline Net domestic assets & 120 & -111 & -109 & -175 & -126 & -104 & -115 \\
\hline Of which: net credit to government & 217 & 92 & 109 & 90 & 86 & 162 & 212 \\
\hline \multirow[t]{2}{*}{ Reserve money } & 268 & 310 & 304 & 355 & 360 & 410 & 466 \\
\hline & \multicolumn{5}{|c|}{ (Contribution to reserve money growth, in percent) } & & \\
\hline Net foreign assets & -54.7 & 101.8 & 98.4 & 35.3 & 24.2 & 7.9 & 16.4 \\
\hline Net domestic assets & 56.3 & -86.3 & -85.3 & -20.7 & -5.6 & 6.0 & -2.6 \\
\hline Reserve money (percent change) & 1.5 & 15.5 & 13.1 & 14.6 & 18.6 & 13.9 & 13.8 \\
\hline Monetary survey & \multicolumn{5}{|c|}{ (Stocks, in billions of Sri Lankan rupees) } & & \\
\hline Net foreign assets & 78 & 366 & 402 & 464 & 475 & 503 & 569 \\
\hline Monetary authorities & 148 & 421 & 412 & 531 & 486 & 514 & 581 \\
\hline Deposit money banks & -70 & -56 & -10 & -67 & -11 & -11 & -12 \\
\hline Net domestic assets & 1,445 & 1,423 & 1,404 & 1,623 & 1,671 & 1,978 & 2,280 \\
\hline Domestic credit & 1,897 & 1,982 & 1,961 & 2,273 & 2,264 & 2,647 & 3,034 \\
\hline Public sector (net) & 619 & 663 & 766 & 724 & 894 & 959 & 1,004 \\
\hline Private sector & 1,278 & 1,319 & 1,196 & 1,549 & 1,370 & 1,688 & 2,029 \\
\hline Other items (net) & -452 & -559 & -557 & -650 & -593 & -669 & -753 \\
\hline \multirow[t]{2}{*}{ Broad money } & 1,523 & 1,789 & 1,806 & 2,087 & 2,146 & 2,480 & 2,850 \\
\hline & \multicolumn{5}{|c|}{ (Annual percent change) } & & \\
\hline Net foreign assets & -65.9 & 370.4 & 417.2 & 26.9 & 18.2 & 5.9 & 13.3 \\
\hline Monetary authorities & -49.4 & 184.4 & 178.2 & 26.0 & 17.8 & 5.8 & 13.1 \\
\hline Deposit money banks & 8.5 & -20.8 & -85.3 & 19.8 & 4.8 & 5.0 & 4.2 \\
\hline Net domestic assets & 22.9 & -1.5 & -2.8 & 14.1 & 19.0 & 18.4 & 15.3 \\
\hline Domestic credit & 18.0 & 4.4 & 3.4 & 14.7 & 15.4 & 16.9 & 14.6 \\
\hline Public sector (net) & 46.2 & 7.1 & 23.7 & 9.2 & 16.8 & 7.2 & 4.8 \\
\hline Private sector & 7.9 & 3.2 & -6.5 & 17.4 & 14.6 & 23.2 & 20.2 \\
\hline \multirow[t]{2}{*}{ Broad money } & 8.5 & 17.5 & 18.6 & 16.7 & 18.8 & 15.6 & 14.9 \\
\hline & \multicolumn{6}{|c|}{ (Contribution to broad money growth, in percent) } & \\
\hline Net foreign assets & -10.7 & 18.9 & 21.3 & 5.5 & 4.0 & 1.3 & 2.7 \\
\hline Net domestic assets & 19.2 & -1.5 & -2.7 & 11.2 & 14.8 & 14.3 & 12.2 \\
\hline Domestic credit & 20.6 & 5.5 & 4.2 & 16.3 & 16.8 & 17.8 & 15.6 \\
\hline Public sector (net) & 13.9 & 2.9 & 9.6 & 3.4 & 7.1 & 3.0 & 1.9 \\
\hline Private sector & 6.7 & 2.6 & -5.4 & 12.9 & 9.7 & 14.8 & 13.7 \\
\hline \multicolumn{8}{|l|}{ Memorandum items: } \\
\hline Broad money multiplier & 5.7 & 5.8 & 6.0 & 5.9 & 6.0 & 6.0 & 6.1 \\
\hline Velocity of broad money & 2.9 & 2.7 & 2.7 & 2.7 & 2.6 & 2.5 & 2.5 \\
\hline Private sector credit (in percent of GDP) & 29.0 & 26.8 & 24.8 & 27.3 & 24.9 & 27.1 & 28.9 \\
\hline
\end{tabular}

Sources: Central Bank of Sri Lanka; and Fund staff projections. 
Table 4. Sri Lanka: Balance of Payments, 2008-2012

(In millions of U.S. dollars, unless otherwise indicated)

\begin{tabular}{|c|c|c|c|c|c|c|c|}
\hline & \multirow[t]{2}{*}{2008} & \multicolumn{2}{|c|}{2009} & \multicolumn{2}{|c|}{2010} & \multirow{2}{*}{$\begin{array}{c}2011 \\
\text { Proj. }\end{array}$} & \multirow{2}{*}{$\frac{2012}{\text { Proj. }}$} \\
\hline & & 1st Review & Prel. & 1st Review & Rev. Prog. & & \\
\hline Current account & $-3,886$ & -130 & -214 & -987 & $-2,444$ & $-2,486$ & $-2,448$ \\
\hline Trade balance & $-5,981$ & $-2,972$ & $-3,122$ & $-3,833$ & $-5,281$ & $-5,529$ & $-5,701$ \\
\hline Exports & 8,110 & 7,237 & 7,085 & 7,800 & 7,912 & 8,355 & 8,886 \\
\hline Imports & 14,091 & 10,209 & 10,206 & 11,633 & 13,193 & 13,884 & 14,587 \\
\hline Non-oil imports & 10,723 & 8,083 & 8,040 & 8,994 & 10,312 & 10,849 & 11,464 \\
\hline Oil imports & 3,368 & 2,126 & 2,167 & 2,638 & 2,881 & 3,035 & 3,123 \\
\hline Services & 401 & 452 & 391 & 498 & 431 & 485 & 545 \\
\hline Income & -972 & -567 & -488 & -618 & -810 & -851 & -893 \\
\hline Transfers & 2,666 & 2,958 & 3,005 & 2,966 & 3,217 & 3,408 & 3,601 \\
\hline Private (net) & 2,565 & 2,866 & 2,927 & 2,891 & 3,147 & 3,338 & 3,541 \\
\hline Official (net) & 101 & 92 & 77 & 75 & 70 & 70 & 60 \\
\hline Capital and financial account & 1,773 & 2,508 & 3,102 & 1,165 & 2,509 & 2,519 & 2,795 \\
\hline Capital transfers (net) & 291 & 108 & 233 & 125 & 218 & 238 & 238 \\
\hline Financial account & 1483 & 1892 & 2361 & 1040 & 2291 & 2281 & 2557 \\
\hline Long-term flows & 1016 & 988 & 1303 & 970 & 2057 & 2081 & 2333 \\
\hline Direct investment & 691 & 560 & 384 & 450 & 680 & 782 & 860 \\
\hline Private sector borrowing $1 /$ & 74 & -123 & 79 & -194 & 11 & -93 & 130 \\
\hline Official sector borrowing & 252 & 551 & 840 & 714 & 1366 & 1392 & 1343 \\
\hline Disbursements & 1,059 & 1,500 & 1,780 & 1,385 & 2,000 & 2,254 & 2,578 \\
\hline Program loans & 23 & 40 & 0 & 50 & 50 & 50 & 50 \\
\hline Project loans & 886 & 960 & 1280 & 1335 & 1950 & 2054 & 2028 \\
\hline Amortization & 807 & 949 & 940 & 671 & 634 & 862 & 1235 \\
\hline Short-term flows & 466 & 904 & 1058 & 70 & 234 & 200 & 224 \\
\hline SDR allocation & 0 & 508 & 508 & 0 & 0 & 0 & 0 \\
\hline Errors and omissions & 728 & 0 & -162 & 0 & 0 & 0 & 0 \\
\hline Overall balance & -1385 & 2378 & 2725 & 179 & 65 & 33 & 346 \\
\hline Financing & 1385 & -2378 & -2725 & -179 & -65 & -33 & -346 \\
\hline Debt service moratorium & 0 & 0 & 0 & 0 & 0 & 0 & 0 \\
\hline NIR (- = increase) & 1385 & -2378 & -2725 & -179 & -65 & -33 & -346 \\
\hline Gross reserves & 1482 & -3268 & -3345 & -1395 & -639 & -864 & -461 \\
\hline Reserve liabilities (- is outflow) & -97 & 890 & 620 & 1216 & 574 & 831 & 115 \\
\hline \multicolumn{8}{|l|}{ Memorandum items: } \\
\hline Current account (in percent of GDP) & -9.8 & -0.3 & -0.5 & -2.3 & -5.2 & -4.9 & -4.5 \\
\hline Gross official reserves (net of ACU debit balances) & 1,580 & 4,849 & 4,925 & 6,244 & 5,564 & 6,428 & 6,889 \\
\hline (In months of imports of goods and nonfactor services) & 1.6 & 4.4 & 4.0 & 5.4 & 4.3 & 4.7 & 4.8 \\
\hline (In percent of short-term debt) & 29 & 87 & 83 & 107 & 88 & 94 & 105 \\
\hline Net international reserves & 1,425 & 3,803 & 4,150 & 3,982 & 4,215 & 4,248 & 4,594 \\
\hline Total stock of public commercial dollar debt $2 /$ & 2,658 & 3,979 & 4,423 & 3,690 & 4,228 & 4,246 & 3,966 \\
\hline GDP (US\$ millions) & 39,596 & 42,150 & 42,203 & 42,032 & 46,929 & 50,763 & 54,661 \\
\hline Oil price (US\$ per barrel) & 97.0 & 60.5 & 61.8 & 74.5 & 80.0 & 83.0 & 84.3 \\
\hline Short-term debt (US\$ million, residual maturity) & 5,367 & 5,566 & 5,915 & 5,821 & 6,353 & 6,853 & 6,587 \\
\hline
\end{tabular}

Sources: Data provided by the Central Bank of Sri Lanka; and Fund staff estimates and projections.

$1 /$ Includes public corporations.

2/ Net of ACU debit balances.

$3 /$ Valued at historical cost through 2002, and at market cost since then.

4/ Comprises Sri Lanka Development Bonds (SLDBs), Foreign Currency Banking Union (FCBU) borrowing and

ther commercial loans.

2/ Comprises SLDBs, FCBUs, and other commercial loans. 
Table 5. Sri Lanka: Preliminary External Financing Requirements, 2008-2012 (In millions of U.S. dollars)

\begin{tabular}{|c|c|c|c|c|c|c|c|}
\hline & \multirow[t]{2}{*}{2008} & \multicolumn{2}{|c|}{2009} & \multicolumn{2}{|c|}{2010} & \multirow{2}{*}{$\begin{array}{c}2011 \\
\text { Proj. }\end{array}$} & \multirow{2}{*}{$\begin{array}{r}2012 \\
\text { Proj. }\end{array}$} \\
\hline & & 1st Review & Prel. & 1st Review & Rev. Prog. & & \\
\hline Current account, including official transfers & $-3,886$ & -130 & -214 & -987 & $-2,444$ & $-2,486$ & $-2,448$ \\
\hline (in percent of GDP) & -9.8 & -0.3 & -0.5 & -2.3 & -5.2 & -4.9 & -4.5 \\
\hline Trade Balance & $-5,981$ & $-2,972$ & $-3,122$ & $-3,833$ & $-5,281$ & $-5,529$ & $-5,701$ \\
\hline Exports & 8,110 & 7,237 & 7,085 & 7,800 & 7,912 & 8,355 & 8,886 \\
\hline Imports & 14,091 & 10,209 & 10,206 & 11,633 & 13,193 & 13,884 & 14,587 \\
\hline Private transfers & 2,565 & 2,866 & 2,927 & 2,891 & 3,147 & 3,338 & 3,541 \\
\hline Other & -470 & -24 & -20 & -45 & -310 & -295 & -288 \\
\hline Amortization & $-1,095$ & $-1,320$ & $-1,353$ & -954 & -917 & $-1,117$ & $-1,501$ \\
\hline Public sector & -807 & -949 & -940 & -671 & -634 & -862 & $-1,235$ \\
\hline Multilateral & -144 & -164 & -164 & -185 & -185 & -211 & -232 \\
\hline Bilateral & -381 & -392 & -392 & -322 & -322 & -356 & -373 \\
\hline Syndicated loans & -282 & -394 & -384 & -164 & -127 & -295 & -631 \\
\hline IMF & -97 & -47 & -102 & -34 & -51 & -12 & -96 \\
\hline Private sector & -191 & -323 & -311 & -250 & -232 & -243 & -170 \\
\hline Change in NFA of commercial banks (- = an increase) & 26 & -250 & -533 & 0 & 0 & 0 & 0 \\
\hline Change in official reserves $(-=$ an increase) & 1,482 & $-3,268$ & $-3,345$ & $-1,395$ & -639 & -864 & -461 \\
\hline Gross external financing requirement & $-3,473$ & $-4,968$ & $-5,444$ & $-3,336$ & $-4,000$ & $-4,467$ & $-4,411$ \\
\hline Sources of financing & 3,473 & 4,030 & 4,723 & 2,086 & 3,375 & 3,624 & 4,200 \\
\hline Borrowing & 1,324 & 1,700 & 2,170 & 1,441 & 2,243 & 2,404 & 2,878 \\
\hline Official Sector Borrowing & 1,059 & 1,500 & 1,780 & 1,385 & 2,000 & 2,254 & 2,578 \\
\hline Multilateral & 358 & 390 & 316 & 430 & 358 & 621 & 442 \\
\hline Bilateral & 551 & 610 & 964 & 955 & 1,642 & 1,483 & 1,636 \\
\hline Syndicated loans & 150 & 500 & 500 & 0 & 0 & 150 & 500 \\
\hline Private Sector Borrowing & 265 & 200 & 390 & 56 & 243 & 150 & 300 \\
\hline Other Capital Account & 2,150 & 1,822 & 2,045 & 645 & 1,132 & 1,220 & 1,322 \\
\hline Capital transfers & 291 & 108 & 233 & 125 & 218 & 238 & 238 \\
\hline FDI inflows & 691 & 560 & 384 & 450 & 680 & 782 & 860 \\
\hline Other (including errors and omissions) & 1,168 & 1,154 & 1,428 & 70 & 234 & 200 & 224 \\
\hline Rupee denominated T-bonds & -213 & 925 & 1,369 & 50 & 144 & 150 & 200 \\
\hline Nonbank private sector (trade credits) & 594 & 112 & 228 & 20 & 55 & 50 & 24 \\
\hline Portfolio investment & 60 & 117 & -6 & 0 & 36 & 0 & 0 \\
\hline Errors and omission & 728 & 0 & -162 & 0 & 0 & 0 & 0 \\
\hline Other & 0 & 0 & 0 & 0 & 0 & 0 & 0 \\
\hline SDR allocation & 0 & 508 & 508 & 0 & 0 & 0 & 0 \\
\hline External financing gap=IMF financing & 0 & -938 & -721 & $-1,251$ & -625 & -843 & -211 \\
\hline Gross official reserves of the Central Bank of Sri Lanka & 1,580 & 4,849 & 4,925 & 6,244 & 5,564 & 6,428 & 6,889 \\
\hline (In months of imports of goods and nonfactor services) & 1.6 & 4.4 & 4.0 & 5.4 & 4.3 & 4.7 & 4.8 \\
\hline
\end{tabular}

Sources: Sri Lankan authorities; and Fund staff estimates and projections. 
Table 6. Sri Lanka: Financial Soundness Indicators - All Banks

\begin{tabular}{|c|c|c|c|c|c|}
\hline & 2006 & 2007 & 2008 & 2009 & $20101 /$ \\
\hline \multicolumn{6}{|l|}{ Capital Adequacy } \\
\hline Regulatory Capital to Risk Weighted Assets(RWCAR) & 13.3 & 14.1 & 13.5 & 16.1 & 15.8 \\
\hline Tier 1 Capital/Risk Weighted Assets(Tier 1 RWCAR) & 12.1 & 12.7 & 11.5 & 14.0 & 13.8 \\
\hline Net Non - Performing Loans to Total Capital Funds & 14.8 & 14.1 & 18.4 & 25.2 & 26.4 \\
\hline Debt to Capital Funds & 238.5 & 220.0 & 210.1 & 153.0 & 151.9 \\
\hline Capital to Assets Ratio & 7.6 & 7.8 & 8.2 & 8.4 & 8.5 \\
\hline \multicolumn{6}{|l|}{ Asset Quality } \\
\hline $\begin{array}{l}\text { Gross Non - Performing Loans (NPL) to Total Gross Loans } \\
\text { (w/o Interest in Suspense) }\end{array}$ & 5.6 & 5.2 & 6.2 & 7.9 & 8.0 \\
\hline $\begin{array}{l}\text { Gross Non - Performing Loans (NPL) to Total Gross Loans } \\
\text { (with Interest in Suspense) }\end{array}$ & 7.4 & 6.8 & 8.0 & 10.2 & 10.3 \\
\hline Net Non-Performing Loans to Total Gross Loans & 1.9 & 1.9 & 2.6 & 4.2 & 4.3 \\
\hline Provision Coverage Ratio (Total) & 66.9 & 64.5 & 59.3 & 49.6 & 48.0 \\
\hline \multicolumn{6}{|l|}{ Earnings \& Profitability } \\
\hline Return on Equity(ROE)-After Tax & 15.2 & 14.0 & 13.9 & 15.2 & 14.3 \\
\hline Return on Assets(ROA)- After Tax & 1.2 & 1.1 & 1.1 & 1.3 & 1.2 \\
\hline Interest Income to Gross Income & 85.5 & 87.4 & 86.2 & 86.0 & 84.1 \\
\hline Staff Expenses to Non Interest Expenses & 43.8 & 44.2 & 43.2 & 46.4 & 46.1 \\
\hline Personnel Expenses to Total Income & 13.0 & 10.5 & 9.5 & 10.6 & 12.0 \\
\hline Total Cost to Total Income & 77.4 & 79.2 & 79.3 & 78.1 & 74.2 \\
\hline Interest Margin & 4.4 & 4.4 & 4.4 & 4.5 & 4.6 \\
\hline \multicolumn{6}{|l|}{ Liquidity } \\
\hline Liquid Assets to Total Assets & 26.7 & 28.1 & 28.2 & 35.2 & 33.8 \\
\hline Statutory Liquid Assets Ratio- & 30.4 & 30.4 & 31.3 & 39.2 & 39.2 \\
\hline \multicolumn{6}{|l|}{ Assets/Funding Structure } \\
\hline Deposits & 69.8 & 69.5 & 69.2 & 74.2 & 73.7 \\
\hline Borrowings & 18.1 & 17.6 & 17.3 & 12.8 & 12.8 \\
\hline Capital to External Funds & 8.6 & 9.2 & 9.5 & 9.6 & 9.8 \\
\hline Credit to Deposits & 86.3 & 88.1 & 86.8 & 71.1 & 72.7 \\
\hline
\end{tabular}

Source: Central Bank of Sri Lanka.

1/ As of March 2010. 
Table 7. Sri Lanka: Reviews and Disbursements under the Proposed Stand-By Arrangement

Original Program

\begin{tabular}{|c|c|c|c|c|}
\hline \multirow[b]{2}{*}{ Date } & \multicolumn{3}{|c|}{ Amount of Purchase } & \multirow[b]{2}{*}{ Condition } \\
\hline & $\begin{array}{l}\text { in percent } \\
\text { of quota }\end{array}$ & & in USD & \\
\hline July 24,2009 & 50 & 206.7 & 312.5 & Approved SBA \\
\hline November 6, 2009 & 50 & 206.7 & 312.5 & $\begin{array}{l}\text { Completion of the first review and } \\
\text { observance of relevant performance }\end{array}$ \\
\hline December 15, 2009 & 50 & 206.7 & 312.5 & $\begin{array}{l}\text { Completion of the second review and } \\
\text { observance of relevant performance }\end{array}$ \\
\hline February 28, 2010 & 50 & 206.7 & 312.5 & $\begin{array}{l}\text { Completion of the third review and } \\
\text { observance of relevant performance }\end{array}$ \\
\hline May 31,2010 & 50 & 206.7 & 312.5 & $\begin{array}{l}\text { Completion of the fourth review and } \\
\text { observance of relevant performance }\end{array}$ \\
\hline August 31, 2010 & 50 & 206.7 & 312.5 & $\begin{array}{l}\text { Completion of the fifth review and } \\
\text { observance of relevant performance }\end{array}$ \\
\hline November 30, 2010 & 50 & 206.7 & 312.5 & $\begin{array}{l}\text { Completion of the sixth review and } \\
\text { observance of relevant performance }\end{array}$ \\
\hline March 15, 2011 & 50 & 206.7 & 312.5 & $\begin{array}{l}\text { Completion of the seventh review and } \\
\text { observance of relevant performance }\end{array}$ \\
\hline
\end{tabular}

Revised Program

\begin{tabular}{|c|c|c|c|c|}
\hline \multirow[b]{2}{*}{ Date } & \multicolumn{3}{|c|}{ Amount of Purchase } & \multirow[b]{2}{*}{ Condition } \\
\hline & $\begin{array}{c}\text { in percent } \\
\text { of quota }\end{array}$ & in SDRs & in USD & \\
\hline July 24, 2009 & 50 & 206.7 & 312.5 & Approved SBA \\
\hline November 6, 2009 & 50 & 206.7 & 312.5 & $\begin{array}{l}\text { Completion of the first review and } \\
\text { observance of relevant performance }\end{array}$ \\
\hline June 28, 2010 & 67 & 275.6 & 416.7 & $\begin{array}{l}\text { Completion of the second and third } \\
\text { review and observance of relevant }\end{array}$ \\
\hline August 15, 2010 & 33 & 137.8 & 208.3 & $\begin{array}{l}\text { Completion of the fourth review and } \\
\text { observance of relevant performance }\end{array}$ \\
\hline November 15, 2010 & 33 & 137.8 & 208.3 & $\begin{array}{l}\text { Completion of the fifth review and } \\
\text { observance of relevant performance }\end{array}$ \\
\hline February 15, 2011 & 33 & 137.8 & 208.3 & $\begin{array}{l}\text { Completion of the sixth review and } \\
\text { observance of relevant performance }\end{array}$ \\
\hline May 15, 2011 & 33 & 137.8 & 208.3 & $\begin{array}{l}\text { Completion of the seventh review and } \\
\text { observance of relevant performance }\end{array}$ \\
\hline August 15, 2011 & 33 & 137.8 & 208.3 & $\begin{array}{l}\text { Completion of the eighth review and } \\
\text { observance of relevant performance }\end{array}$ \\
\hline November 15, 2011 & 33 & 137.8 & 208.3 & $\begin{array}{l}\text { Completion of the ninth review and } \\
\text { observance of relevant performance }\end{array}$ \\
\hline February 15, 2012 & 33 & 137.8 & 208.4 & $\begin{array}{l}\text { Completion of the tenth review and } \\
\text { observance of relevant performance }\end{array}$ \\
\hline Total & 400 & 1653.6 & 2500 & \\
\hline
\end{tabular}




\section{ATTACHMENT I \\ SRI LANKA: LETTER OF INTENT}

Colombo, June 19, 2010

Mr. Dominique Strauss-Kahn

Managing Director

International Monetary Fund

Washington, D.C. 20431

Dear Mr. Strauss-Kahn:

This letter serves as a supplement to the July 16, 2009, Memorandum of Economic and Financial Policies and our October 30, 2009, Letter of Intent.

1. The macroeconomic environment in Sri Lanka continues to improve following the end of the conflict and the approval of the Stand-By Arrangement with the International Monetary Fund. Output growth is rebounding and inflation remains subdued in single digits. Rising investor confidence and an increase in remittances have allowed us to rebuild international reserves from very low to now comfortable levels.

2. With the peace restored and following the Presidential and parliamentary elections, we now face a unique opportunity to ensure continuity in policies that have been initiated in recent times to put Sri Lanka on a path of higher, sustainable future growth and prosperity as per the Mahinda Chintana vision for the future. Critical to this will be policies that ensure that macroeconomic stability is maintained while allowing for much-needed infrastructure investment to boost growth prospects and address the development challenges in lagging regions, including the conflict-affected north and east.

3. The government's economic program is ambitious in a wide range of areas, including steps toward (i) fiscal consolidation through continued enhancement of the quality of public spending; (ii) rationalization of the tax system; (iii) improvement in state-owned enterprise performance; and (iv) further strengthening of the financial sector. We continue to believe that our program with the IMF has strengthened the government's efforts toward its policy goals. With the near-term risk of an external crisis averted, the program's emphasis can now shift toward growth-enhancing policies that address some of the economy's key structural weaknesses. In line with this, and to support the wide range of policy reforms that we will be undertaking during this period, we wish to extend through end-2011 our program with the IMF, which we see as a mitigating arrangement against external vulnerabilities.

4. While acknowledging the risks in the global economic environment, the government's policy framework aims at achieving economic growth in excess of 8 per cent, 
while containing inflation at a moderate level. The higher growth is to be achieved by further strengthening the enabling environment for the real economy-in particular, agriculture, SMEs, and other value-adding industries - to respond more positively. This will require a significant boost in investment, and we have already begun steps to improve the investment climate and the ease of doing business. On the approval of the Cabinet of Ministers, a high level committee headed by the Senior Advisor to the President, with technical support from the relevant agencies, has been appointed to identify laws and regulations obstructing investment. Moreover, line ministries are actively identifying specific areas in which to attract foreign direct investment, including from the private sector. The Ministry of Economic Development, the Board of Investment (BOI), and the Department of National Planning will jointly work out a new investment strategy based on such information to ensure that projects supported under a new investment incentive regime are carefully selected and better targeted - the aim would be to shift the emphasis away from a heavy reliance on tax concessions towards greater predictability of the investment regime and increasing the ease of doing business, mainly by coordinating the development activities of different ministries, public institutions and other agencies. Progress to this end will be a focus of discussions during the next review.

5. The budget deficit in 2009 reached 9.9 percent of GDP, including rehabilitation expenditures, against a program target of 7 percent. The main factors for the overrun were faster-than-expected aid disbursements for infrastructure projects, higher interest payments, a shortfall in revenue, and post-conflict rehabilitation and humanitarian expenditure, as well as costly demining of conflict affected areas. Although the 2009 budget outturn, particularly in the context of the continuing adverse impact of global economic conditions, calls for some recalibration of fiscal targets, the program's original goals of fundamental and sustainable deficit reduction remain unchanged. Spending for the first four months was managed by the Vote on Account approved by the parliament, and thereafter, until the budget for 2010 is passed by the parliament, spending has been strictly limited, as authorized under the Presidential directive based on Section 150 of the Constitution. On June 8, the government submitted to parliament a budget covering the full-year 2010 spending envelope consistent with a deficit of 8 percent of GDP, a 2 percentage point decline from 2009. Deficit reduction will take place primarily through a reduction in security-related spending due to lower procurement spending and a reduction in other non-interest recurrent spending, including by maintaining subsidies and transfers in nominal terms. Despite a significant reduction in current expenditure (by 1.3 percent of GDP relative to 2009), we recognize that the deficit will exceed our original target of 6 percent of GDP, or 7 percent including reconstruction spending. The higher deficit comes from the higher-than-earlier-expected interest payments, and more cautious revenue projections, given the uncertainty in the speed of recovery of external trade sector activity. Parliamentary approval of the 2010 budget is expected in July. Until the budget is passed, we will continue to restrict spending under the Presidential directive consistent with our full-year deficit target. 
6. Beyond 2010, we remain committed to further fiscal consolidation in terms of the broad framework stipulated in the Fiscal Management Responsibility Act (FMRA) to reduce the budget deficit. We have thus set a fiscal deficit target of 6.8 percent for 2011 and 5 percent for 2012, and, as required by the FMRA, this medium-term deficit reduction strategy will be presented to with the 2011 budget due in November 2010. The 2011 budget will continue to implement the growth-oriented fiscal and structural policies outlined below. Submission of this budget to Parliament is expected in November 2010.

7. We have developed a plan for comprehensive reform of our tax system in order to make it more conducive to private-sector growth and to reverse the declining trend in tax revenues, so as to support needed reconstruction and infrastructure investment. According to the timetable for this reform plan, we have launched key reforms now, followed by further reforms during the remaining months of 2010 and legislative changes as part of the 2011 budget. Taking into consideration the Presidential Tax Commission's recommendations, key goals of the Government's tax reform plan are to simplify the existing tax system, broaden the base, and improve tax administration, with the aim to bring about a sustainable increase in tax revenue. Specifically, the reform will focus on the following areas.

- Streamlining trade and excise taxes: We have already taken steps to simplify a number of trade and excise taxes. The government has reduced the number of tariff bands to four-viz., $0,5,15$, and 30 percent - and exemptions will be allowed only on the grounds of national security, health, environment, and international commitments, thus streamlining the dual customs duty structure prevailing for almost ten years. Import surcharges have been incorporated into the new duty structure, and remaining duty waivers granted to limit the impact of high international commodity prices in 2009 are being phased out. Beyond these changes, prohibitive excise taxes applicable on a wide range of items including motor vehicles have been simplified. Moreover, most essential commodities that are being imported and subjected to about ten different taxes will now face a unified "special commodity levy" to make tax administration more efficient and taxation simpler.

- Reducing tax concessions: One key element of reforms described above will be to reduce lost tax revenue from various concessions including ad hoc tax holidays and duty exemptions. The budget proposal announced in 2008 to cap new tax holidays and limit the granting of exemptions under section 17 of the BOI Act will be taken into consideration in the context of formulation the new incentive regime. The implementation of these together with a new tax incentive regime will be announced before end 2010. We have requested the Board of Investment to reformulate the investment strategy and refrain from granting new concessions until new regulations are finalized. These measures are expected to make a significant contribution to growth and increase in revenue elasticity in the medium term. 
- Broadening the VAT and income tax bases: The operational modalities of the VAT system and income taxes need simplification to eliminate weaknesses, including the complex and cumbersome VAT refund mechanism, and to improve revenue collection. We have sought technical assistance, with a view to taking concrete steps for improvement. In addition, taking into account the tax commission's recommendations, our specific actions under review include reducing the number of numeral taxes and broadening the base of remaining taxes. The enabling legislation required for these tax reforms will be finalized as part of the 2011 budget. We expect to make significant progress toward this goal by the time of the next review.

- Improving tax administration: With financial support from the Asian development Bank under the Fiscal Management Efficiency Project, action has already begun for simplification of procedures and processes, management information system, human resource development, tax audit, and IT use.

These initiatives together with expected private sector investment and growth will sufficiently broaden the tax base and improve the revenue-to-GDP ratio to $15 \frac{1}{2}$ percent in 2011 , with the aim of reaching 161/2 percent by 2012 .

8. Improving the performance and efficiency of loss-making state enterprises will help free resources for infrastructure investment and lending to the private sector. Newly reconstituted management in key public enterprises is expected to improve the performance of these enterprises. A separate Ministry of State Resources and Enterprise Development has been established to concentrate on under-performing state assets and addressing the issues in loss-making enterprises. Electricity prices are comparatively high in Sri Lanka, and a committee has been set up to rationalize the tariff regime and also address the high cost structure by utilizing low-cost coal and alternative energy sources. The government is also committed to dealing with the restructuring of non-performing debt of SOEs, including the Ceylon Petroleum Corporation and Ceylon Electricity Board.

9. We continue to remain committed to maintain exchange rate flexibility that reflects market conditions. Monetary policy aims at maintaining price stability while ensuring adequate provision of credit to the private sector. The Central Bank of Sri Lanka also intends to further promote capital inflows, inward investments, and remittances.

10. The comprehensive financial sector regulatory reform agenda remains on track. Prudential regulations for credit card companies and payment service providers (structural benchmark) have been issued. The CBSL intends to issue guidelines to improve banks' integrated risk management frameworks by end-July 2010. In addition, guidelines to enhance consumer protection will be issued by end-September 2010 to improve transparency and disclosure of banks' business practices. Amendments to the Finance Companies Act clarifying the legal authority of the Central Bank in enforcing its regulations on all deposit- 
taking finance companies are to be submitted to Parliament (structural benchmark). Amendments to the Banking Act will also be submitted to Parliament by end-September), incorporating comments already received by stakeholders.

\section{The CBSL Roadmap for Monetary and Financial Sector Policies for 2010 and}

Beyond also announced a number of new reform initiatives including the creation of a deposit insurance fund, regulation of pension funds, and capital market development.

- The proposed deposit insurance scheme under the Monetary Law Act (MLA) will have a clear governance structure and can be mandated on all licensed banks and finance companies, with the issuance of implementation regulations by end-August 2010 (new structural benchmark). The premiums charged will initially be based on broadly flat rates, with a view to moving toward a more risk-based charging approach later on.

- The government is proposing to introduce a comprehensive regulatory framework for private-sector superannuation funds by empowering an existing regulatory body (Insurance Board of Sri Lanka) to undertake this function by end-December 2010 (structural benchmark).

- The government is planning measures to develop the capital market. These measures focus on diversifying the investor base, such as relaxing the restrictions on foreign investors' participation in the corporate bond market, as well as encouraging listing of securities, and developing a medium-term, benchmark-oriented government debt issuance strategy.

12. Beyond these changes, our policy agenda remains as described in the July 16, 2009 Memorandum of Economic and Financial Policies. We have set program performance criteria for end-June 2010 and end-September 2010, in addition to the respective reviews (Table 1). In view of Sri Lanka's graduation, in the IMF's classification, from low-income to middle-income emerging economy status, we request the elimination of the performance criterion setting a ceiling on non-concessional debt contracted and guaranteed by the government; our borrowing and government guarantee limits are stipulated in the FMRA and the annual borrowing limits authorized by the parliament. We are of the view that the debt dynamics are favourable, indicating that there is further scope for capital market participation.

13. As we have met all end-March 2010 performance criteria, and given our demonstrated strong commitment to the program to date, we request completion of the second and third reviews of the Stand-By Arrangement, following which we intend to draw two tranches amounting to SDR 275.6 million. We request that the SBA be extended by 12 months and that the remaining tranches be rephased accordingly. The fourth review is 
contemplated to be completed on or after August 15, 2010 and the fifth review is contemplated to be completed on or after November 15, 2010.

14. We believe that the policies set forth in the July 16, 2009 letter, the October 30, 2009 letter, and in this letter are adequate to achieve the objectives of our economic program, but the Government stands ready to take additional measures as appropriate to ensure achievement of its objectives. As is standard under all IMF arrangements, we will consult with the IMF before modifying measures contained in this letter, or adopting new measures that would deviate from the goals of the program, and provide the IMF with the necessary information for program monitoring.

15. In keeping with its policy of transparency, the Government has authorized the publication of this letter and the attached Technical Memorandum of Understanding.

Sincerely yours,

/s/

Sarath Amunugama

Deputy Minister of Finance and Planning

and Senior Advisor to His Excellency the President /s/

Ajith Nivard Cabraal

Governor, Central Bank of Sri Lanka 
Table 1. Sri Lanka: Quantitative Performance Criteria (PC) and Indicative Targets (IT)

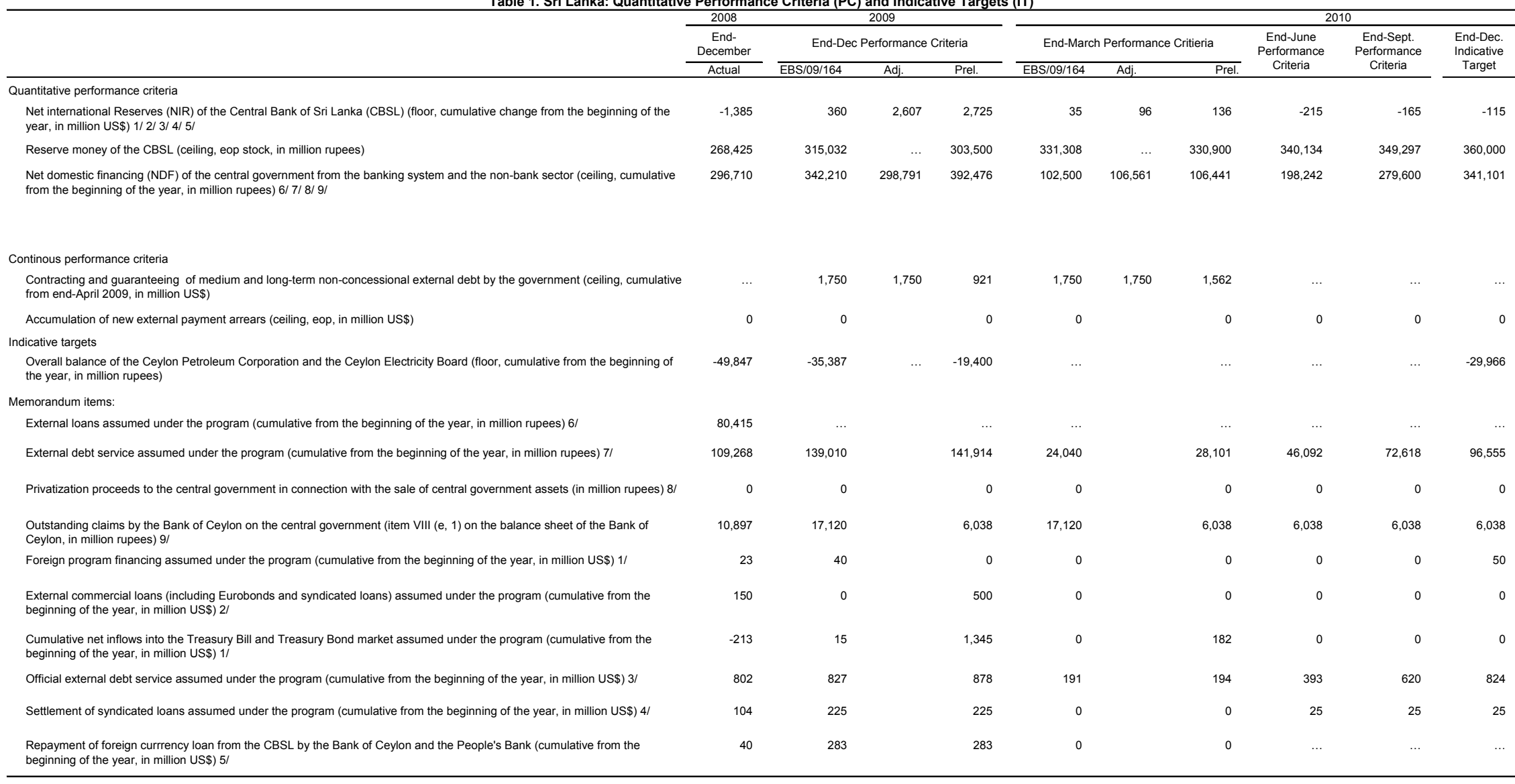

1/ If the amount of program financing and the cumulative net inflows into the Treasury Bill market and Treasury Bond market is higherllower in U.S. dollar terms than assumed under the program, the floor on NIR will be adjusted upward/downward by the cumulative differences on the test $2 /$ If the amount of commercial borrowing (including Eurobonds and syndicated loans) is higherllower in U.S. dollar terms than assumed under the program, the floor on NIR will be adjusted upward/downward by the cumulative difference on the test date. 3/ I the amount of official external debt service by the central government in U.S. dollars is higher/lower than assumed under the program, the floor on NIR will be adjusted downward/upward by the cumulative differences on the test date.

4/ If the amount of debt service on syndicated loans by the central government in U.S. dollars is higher/lower than assumed under the program, the floor on NIR will be adjusted downward/upward by the cumulative differences on the test date. The adjustor is introduced from end-December 2009.

$5 /$ The floor on NIR will be adjusted upwards by any repayments for the foreign currency loan from the CBSL by the Bank of Ceylon and the People's Bank in excess of the repayment schedule. This adjustor is not applicable from January 2010 onwards. 6/ If the amount of external loans is higherlower in rupee terms than assumed under the program, the cumulative ceiling on net domestic financing of the central government will be adjusted downward/upward by the cumulative difference in external loans on the test date. From end-

$7 /$ If the amount of external debt service by the central government in rupee terms is higher/lower than assumed under the program, the ceiling on net domestic financing of the central government will be adjusted upward/downward by the cumulative difference in external debt service

$8 /$ If the amount of privatization proceeds to the central government in connection with the sale of central government assets is higher/lower than assumed under the program, the cumulative ceiling on NDF of the central government will be adjusted downward/upward by the cumulative
receiptreimbursement of any privatization proceeds. 9/If the amount of outstanding claims by the Bank of Ceylon on the central government (item VIII (e, 1) on the balance sheet of the Bank of Ceylon) is lower in rupee terms than assumed under the program, the NDF of the central government will be adjusted upward by the difference on the test date. 
Table 2. Sri Lanka: Structural Benchmarks (SB)

\begin{tabular}{|c|c|c|}
\hline Structural Benchmarks & Date & Status \\
\hline Recapitalization of Seylan Bank through a public share issuance. & 9/30/2009 & Implemented \\
\hline $\begin{array}{l}\text { A contingency plan for orderly workouts of problem banks and financial institutions will be developed by } \\
\text { the CBSL. }\end{array}$ & 9/30/2009 & Implemented \\
\hline $\begin{array}{l}\text { Approval by the Monetary Board of a revised Banking Act and other pertinent laws and legislations that: } \\
\text { (i) improve the bank resolution framework that more clearly defines the provisions for acquisition, and } \\
\text { roles of the conservator and liquidator; and (ii) strengthens the definition of large exposures and related } \\
\text { parties to better capture all material risks. }\end{array}$ & 9/30/2009 & Implemented \\
\hline $\begin{array}{l}\text { Submission by the tax review commission of an interim report, including on base broadening measures } \\
\text { to be incorporated into the } 2010 \text { budget. }\end{array}$ & $10 / 15 / 2009$ & Implemented with delays \\
\hline $\begin{array}{l}\text { Approval by Parliament of an interim budget for the first four months of } 2010 \text { consistent with program } \\
\text { targets. }\end{array}$ & $12 / 15 / 2009$ & Implemented \\
\hline Develop a plan to address outstanding debts between the CEB, CPC and state-owned banks. & $12 / 31 / 2009$ & Implemented \\
\hline $\begin{array}{l}\text { Issuance of prudential regulations and guidelines to credit card companies and payment service } \\
\text { providers. }\end{array}$ & $12 / 31 / 2009$ & Implemented \\
\hline Submission to parliament of the 2010 budget consistent with program targets. & $4 / 30 / 2010$ & Not met \\
\hline $\begin{array}{l}\text { Submission to the parliament of a revised Finance Company Act which includes clarifying the legal } \\
\text { authority of the CBSL in enforcing its regulations on all deposit taking finance companies. }\end{array}$ & $5 / 31 / 2010$ & Delayed \\
\hline $\begin{array}{l}\text { Submission by the Presidental Tax Commission of a final report, including specific tax reform } \\
\text { measures. }\end{array}$ & $8 / 31 / 2010$ & Structural Benchmark \\
\hline Parliamentary approval of full-year 2010 budget consistent with program targets & $8 / 31 / 2010$ & Structural Benchmark \\
\hline Issuance of regulations to establish a deposit insurance scheme. & $9 / 30 / 2010$ & Structural Benchmark \\
\hline $\begin{array}{l}\text { Submission to parliament of the } 2011 \text { budget consistent with program targets, including income tax and } \\
\text { VAT reform measures. }\end{array}$ & $11 / 30 / 2010$ & Structural Benchmark \\
\hline Introduce a regulatory framework for private-sector superannuation funds. & $12 / 31 / 2010$ & Structural Benchmark \\
\hline
\end{tabular}




\section{ATtaChMENT II}

\section{Technical Memorandum of Understanding}

1. This Technical Memorandum of Understanding sets out a framework for monitoring the performance of Sri Lanka under the program supported by the StandBy Arrangement (SBA). It specifies the performance criteria and indicative targets (including adjustors) under which Sri Lanka's performance will be assessed through quarterly reviews, starting with the performance criteria for end-June 2010. Monitoring procedures and reporting requirements are also specified. The fourth review will take place on or after August 15, 2010, the fifth review on or after November 15, 2010, 2010, and the sixth review on or after February 15, 2011.

\section{Fiscal TARgets}

\section{A. Performance Criterion on Net Domestic Financing of the Central Government}

2. Net domestic financing (NDF) is defined as the change in net credit to the central government by the domestic banking system and the net change in holdings of treasury bills and other government securities by the domestic non-bank sector. For the purpose of program monitoring, the central government is defined to include line ministries, departments, and other public institutions. The Central Bank of Sri Lanka (CBSL), stateowned enterprise, parastatals and other agencies that do not receive subventions from the central government are excluded from the definition of central government. NDF of the central government is defined as the sum of (i) net borrowing from the CBSL (ways and means advances, loans, holdings of treasury bills, treasury bonds, and other central government bonds minus deposits); (ii) net borrowing from domestic commercial banks and the domestic non-bank sector (loans, advances, holdings of restructuring bonds, and holdings of treasury bills and other central government securities minus deposits); and foreign holdings of Treasury Bills and Treasury Bonds. In 2009, NDF of the central government defined in this manner amounted to Rs. 392.5 billion. Of this amount, Rs. 49.0 billion was net borrowing from the domestic banking system, Rs. 185.2 billion was net borrowing from the domestic non-bank sector, Rs. 146.9 billion was net foreign inflows into the Treasury Bill and Treasury Bond markets and Rs. 11.3 billion was net borrowing from other sources.

\section{The following adjustment will apply:}

3. If the amount of external program loans and external commercial loans (including Eurobonds and syndicated loans) to the central government - as set out in Table 1 - is higher/lower in rupee terms than assumed under the program, the cumulative ceiling on NDF of the central government will be adjusted downward/upward by the cumulative difference on the test date. 
4. If the amount of external debt service by the central government in rupee terms - as set out in Table 1 - is higher/lower than assumed under the program, the cumulative ceiling on NDF of the central government will be adjusted upward/downward by the cumulative difference in external debt service payments measured in rupees.

5. If the amount of privatization proceeds to the central government in connection with the sale of central government assets - as set out in Table 2 - is higher/lower than assumed under the program, the cumulative ceiling on NDF of the central government will be adjusted downward/upward by the cumulative receipt/reimbursement of any privatization proceeds.

6. If the amount of outstanding claims by the Bank of Ceylon on the central government (item VIII (e, 1) on the balance sheet of the Bank of Ceylon) - as set out in Table 3-is lower in rupee terms than assumed under the program, the NDF of the central government will be adjusted upward by the difference on the test date.

\section{B. Indicative Target on the Sum of the Overall Balance of the Ceylon Electricity Board and the Ceylon Petroleum Corporation.}

7. The balance of the overall profit or loss position of the Ceylon Electricity Board (CEB) and the Ceylon Petroleum Corporation (CPC) from their operating income statements is measured from above the line on an accrual basis. At end-December 2009, the sum of that overall position of the CEB and CPC defined in this manner stood at Rs. -19.4 billion.

\section{MONetary TARgets}

\section{A. Performance Criterion on Reserve Money of the CBSL}

Reserve money of the CBSL consists of currency in circulation (with banks and with the rest of the public), financial institutions' domestic currency deposits at the CBSL, and the deposits of following government agencies: the National Defense Fund (General Ledger Acc. No. 4278), the Buddha Sasana Fund A/C (General Ledger Acc. No. 4279); and the Road Maintenance Trust Fund (General Ledger Acc. No. 4281). At end-December 2009, reserve money defined in this manner stood at Rs. 303.5 billion. For the purpose of program monitoring, reserve money on the test date shall be measured as average reserve money during the prevailing reserve week (Friday to Thursday).

The following adjustment will apply:

8. If any bank fails to meet its legal reserve requirement, the ceiling on reserve money will be adjusted downward to the extent of any shortfall in compliance with the requirement.

9. Changes in required reserve regulations will modify the reserve money ceiling according to the formula:

$$
\Delta M=\Delta r B_{0}+r_{0} \Delta B+\Delta r \Delta B
$$


where $\Delta M$ denotes the change in reserve money, $r_{0}$ denotes the reserve requirement ratio prior to any change; $B_{0}$ denotes the reservable base in the period prior to any change; $\Delta r$ is the change in the reserve requirement ratio; and $\Delta B$ denotes the immediate change in the reservable base as a result of changes to its definition.

\section{EXTERnAl SeCtOR TARgETS}

\section{A. Performance Criterion on Net Official International Reserves}

10. Net official international reserves (NIR) is defined as (i) the difference between the gross foreign assets and liabilities of the CBSL and (ii) the balance of State Treasury's (DSTs) Special Dollar and Yen Revolving accounts, both expressed in terms of market values. Gross foreign assets of the CBSL consists of monetary gold; foreign exchange balances held outside Sri Lanka; foreign securities (valued in market prices); foreign bills purchased and discounted; the reserve position at the IMF and SDR holdings; and the Crown Agent's credit balance. Excluded from gross foreign assets will be participation in international financial institutions; holdings of nonconvertible currencies; holdings of precious metals other than monetary gold; claims on residents (e.g., statutory reserves on foreign currency deposits of commercial banks and central bank foreign currency deposits with resident commercial banks) pledged, non-liquid, collateralized or otherwise encumbered foreign assets (such as the government's war risk insurance deposit with Lloyds during 2001/02); and claims in foreign exchange arising from derivative transactions (such as futures, forwards, swaps and options). Gross foreign liabilities are all foreign currency denominated liabilities of the CBSL to non-residents; the use of Fund credit; Asian Clearing Union debit balance and commitments to sell foreign exchange arising from derivatives such as futures, forwards, swaps, and options. In addition, NIR will include the balance of the DSTs' Special Dollar and Yen Revolving accounts. DST accounts are foreign currency accounts held by the Treasury and managed by the CBSL as an agent of the government. At end-December 2009, NIR defined in this manner stood at U.S. dollars 4,150 million.

\section{The following adjustment will apply:}

11. If the amount of foreign program financing and the cumulative net foreign inflows into the Treasury Bill or Treasury Bond market - as set out in Table 4-is higher/lower in U.S. dollar terms than assumed under the program, the floor on NIR will be adjusted upward/downward by the cumulative differences on the test date.

12. If the amount of commercial borrowing (including Eurobonds and syndicated loans) - as set out in Table 4-is higher/lower in U.S. dollar terms than assumed under the program, the floor on NIR will be adjusted upward/downward by the cumulative difference on the test date.

13. If the amount of official external debt service by the central government in U.S. dollar terms (including debt service on syndicated loans) - as defined in Table 4-is higher/lower 
than assumed under the program, the floor on the NIR will be adjusted downward/upward by the cumulative difference in official external debt service payments.

14. The floor on NIR will be adjusted upward for any increase in Sri Lanka's allocation of Special Drawing Rights (SDR) from the IMF. Sri Lanka's SDR allocation at the time of approval of this arrangement amounted to SDR 70.868 million.

\section{B. Performance Criterion on External Payment Arrears}

\section{A continuous performance criterion applies to the nonaccumulation of external} payments arrears on external debt contracted or guaranteed by the central government (as defined in 92) or the CBSL. External payments arrears consist of external debt-service obligations (principal and interest) on debt as defined in $\$ 16$ that have not been paid at the time they are due, as specified in the contractual agreements. However, overdue debt and debt service obligations that are in dispute will not be considered as external payments arrears for the purposes of program monitoring.

\section{DATA REPORTING REQUIREMENTS}

16. Sri Lanka shall provide the Fund, through reports at intervals or dates requested by the Fund, with such information as the Fund requests in connection with the progress of Sri Lanka in achieving the objectives and policies set forth in the Memorandum of Economic and Financial Policies. All the program monitoring data will be provided by the Ministry of Finance and the Central Bank of Sri Lanka (CBSL). Data relating to the external and monetary targets will be furnished within no more than three weeks after the end of each month. ${ }^{1}$ With regards to the fiscal targets, the data in table 5 will be furnished within no more than five weeks after the end of each month and the data in table 6 within no more than nine weeks after the end of each month. For the overall balance of the CEB and the CPC, estimates will be available within four weeks.

17. For the purpose of monitoring the fiscal performance under the program, data will be provided in the format as shown in Tables 5 and 6.

18. For the purpose of monitoring the monetary targets under the program, data will be provided in the format shown in Table 7.

19. For the purpose of monitoring the external sector performance under the program, data will be provided in the format shown in Tables 8 and 9.

\footnotetext{
${ }^{1}$ The deadline for submitting monetary and external data for end-December 2010 will be five weeks due to the added time needed to close the books at the end of the year.
} 
Table 1. Sri Lanka: External Financing Assumptions (cumulative from the beginning of the year, in millions of rupees)

\begin{tabular}{lrrr}
\hline & \multicolumn{3}{c}{2010} \\
\\
\cline { 2 - 4 } External Program Loans & June & Sept & Dec \\
External Commercial Loans & 0 & 0 & 50 \\
External Debt Service & 46,092 & 72,618 & 96,555 \\
\hline
\end{tabular}

Table 2. Sri Lanka: Assumptions on Privatization Proceeds (Cumulative from the beginning of the year, in millions of rupees)

\begin{tabular}{|c|c|c|c|}
\hline & \multicolumn{3}{|c|}{2010} \\
\hline & June & Sept & Dec \\
\hline Privatization Proceeds & 0 & 0 & 0 \\
\hline
\end{tabular}

Table 3. Sri Lanka: Outstanding Claims by the Bank of Ceylon on the Central Government

(item VIII $(e, 1)$ on the balance sheet of the Bank of Ceylon, in millions

\begin{tabular}{lrrr}
\hline & \multicolumn{3}{c}{2010} \\
Foreign Bills Inward & June & Sept & Dec. \\
\cline { 2 - 4 } & 6,038 & 6,038 & 6,038 \\
\hline
\end{tabular}

Table 4. Sri Lanka: External Financing for NIR Purposes (Cumulative from the beginning of the year, in millions of U.S. dollars)

\begin{tabular}{lrrr}
\hline & \multicolumn{3}{c}{2010} \\
& June & Sept & Dec \\
\hline Program Loans & 0 & 0 & 50 \\
External Commercial Loans & 0 & 0 & 0 \\
Treasury Bills/Bonds & 0 & 0 & 0 \\
Official External debt service & 393 & 620 & 824 \\
Settlement of Syndicated Loans & 25 & 25 & 25 \\
\hline
\end{tabular}


Table 5. Sri Lanka: Summary of Central Government Operations 1/

(In millions of rupees)

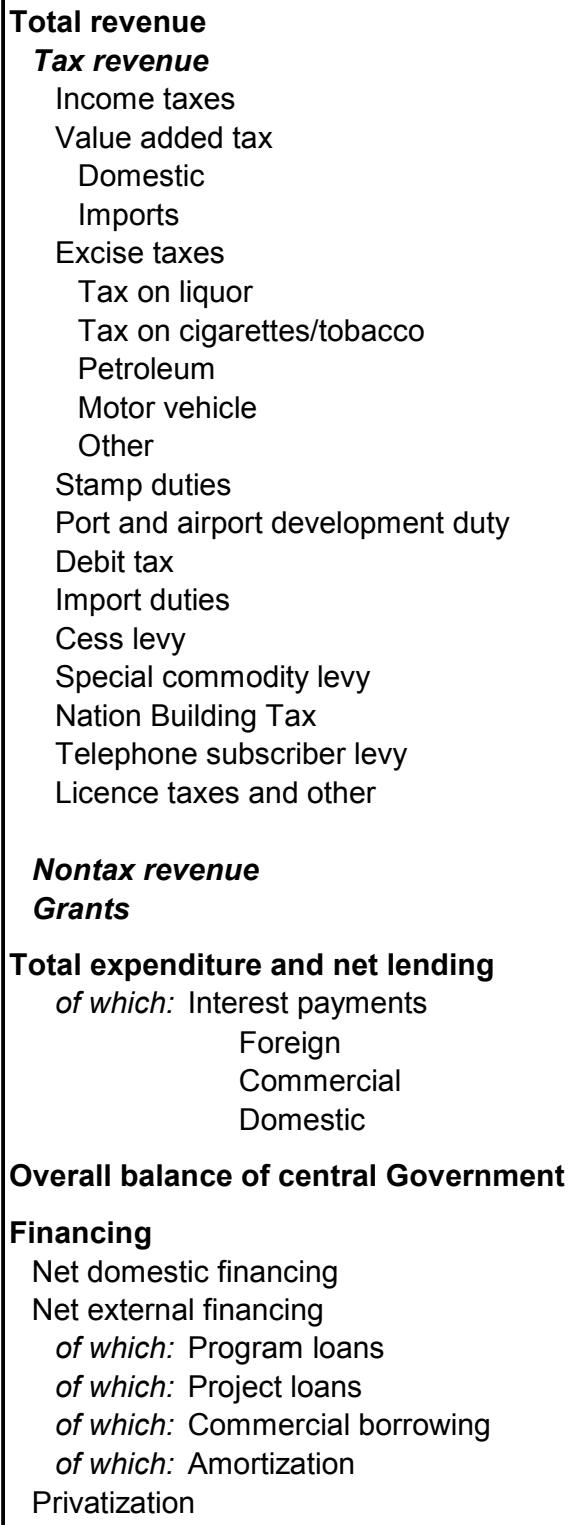

Total expenditure and net lending of which: Interest payments

Foreign

Commercial

Domestic

Overall balance of central Government

Financing

Net domestic financing

Net external financing

of which: Program loans

of which: Project loans

of which: Commercial borrowing

of which: Amortization

Privatization

$1 /$ As agreed for the purpose of monitoring the program 
Table 6. Sri Lanka: Central Government Expenditure 1/

(In millions of rupees)

Total expenditure and net lending

\section{Current expenditure}

Civil service wages and salaries

Other civilian goods and services

Security related expenditure

Subsidies and transfers

Households

Of which: Samurdhi

Pensions

Fertilizer

Institutions, corporations, other government agencies

Interest payments

Foreign

Commercial

Domestic

Capital expenditure and net lending

$1 /$ As agreed for the purpose of monitoring the program

Table 7. Sri Lanka: Balance Sheet of the Central Bank 1/

(In millions of rupees)

Net foreign assets

Foreign assets

Cash and balances abroad

Foreign securities

Claims on ACU

SDRs

IMF related assets

Receivables

Foreign currency reserve

Foreign liabilities

IMF and nonresident account

Liabilities to ACU

Net domestic assets

Claims on government

Advances

Treasury bills and bonds

Cash items in collection

Government deposits

Claims on commercial banks

Medium and long term

Short term

Other items net

Reserve money

Currency in circulation

Commercial bank deposits

Government agencies deposits

$1 /$ As agreed for the purpose of monitoring the program 
Table 8. Sri Lanka: Summary of Central Bank Foreign Exchange Operations 1/

(In millions of USD)

1. Total inflows

Loans

Program

IMF

Project (cash component only)

Interest earnings, forex trading profits, cap gains

Purchases of foreign exchange

Change in balances in DST's A/Cs

Other inflows

Borrowing from SLDBs

Loans from FCBUs

Syndicated Loans

Commercial loans

Repayments of BOC and PB claims

2. Total outflows

Public Debt Service Payments

Amortization

Principal (foreign loans)

Settlement SLDBs

Settlement FCBU

Settlement of syndicated loans

Interest

Foreign loans

Domestic foreign currency loans

Payments to the IMF/ change in valuation of liabilities

Foreign exchange sales to commercial banks

Foreign exchange deposits at BOC and PB

3. Net flow at current rates (1-2)

Net International Reserves

Gross International Reserves

Cumulative net inflows into the Treasury Bill/Bond market

$1 /$ As agreed for the purpose of monitoring the program 


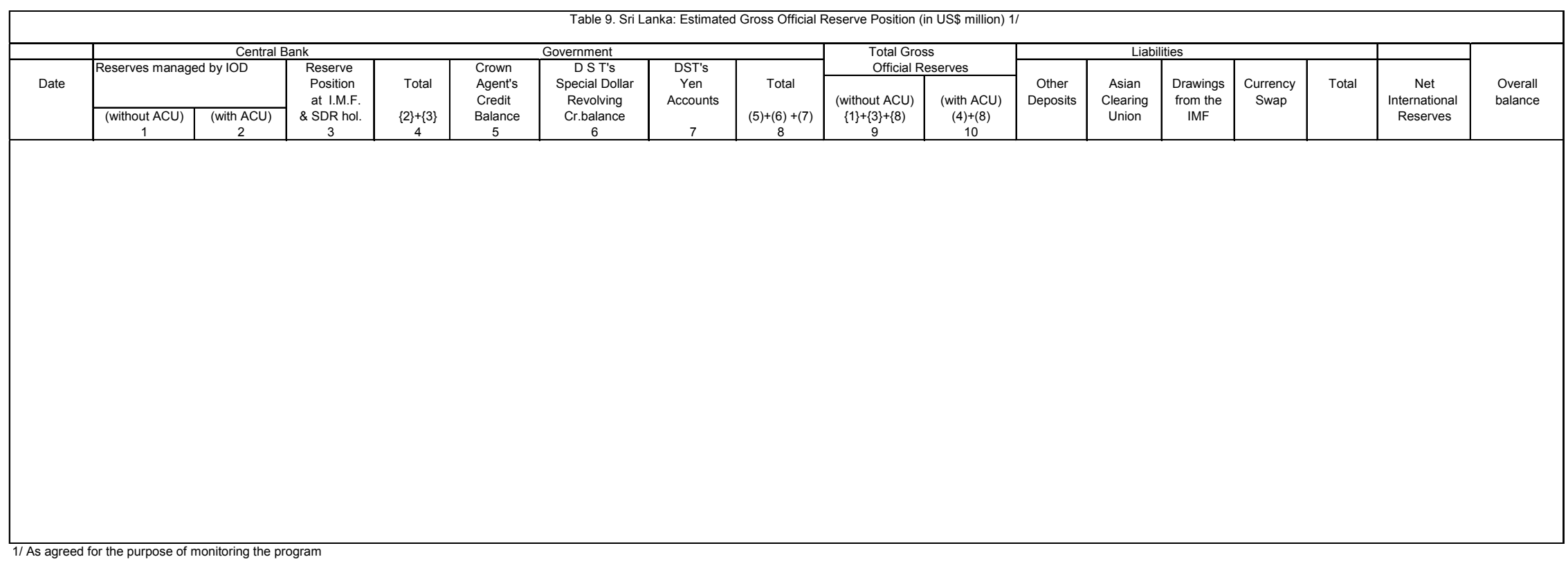


Press Release No. 10/264

International Monetary Fund

FOR IMMEDIATE RELEASE

Washington, D.C. 20431 USA

June 28, 2010

\section{IMF Executive Board Completes Second and Third Reviews Under Stand-By Arrangement with Sri Lanka and Approves US\$407.8 Million Disbursement}

The Executive Board of the International Monetary Fund (IMF) today completed the second and third reviews of Sri Lanka's economic performance under a program supported by a Stand-By Arrangement (SBA). The completion of the reviews enables the immediate disbursement of an amount equivalent to SDR 275.6 million (about US\$407.8 million), bringing total disbursements under the arrangement to an amount equivalent to SDR 689.0 million (about US\$1,019.4 million).

The Executive Board also approved a request by the Sri Lankan authorities for a one-year extension of the SBA and accordingly a rephasing of the future disbursements into seven equal amounts of SDR 137.8 million (about US\$203.9 million) in light of the recent delay in the program.

The SBA was approved on July 24, 2009 (see Press Release No. 09/266) for an amount equivalent to SDR 1,653.6 million (about US\$2,446.7 million) or 400 percent of Sri Lanka's quota.

Following the Executive Board's discussion on Sri Lanka, Mr. Naoyuki Shinohara, Deputy Managing Director and Acting Chair, stated:

"Overall economic conditions in Sri Lanka are improving and the economy is likely to show strong growth this year. Inflation remains subdued and average inflation for the year as a whole is expected to remain in the single digits. External balances are strong, remittance inflows continue at a high rate, tourism prospects are strengthening rapidly, and gross reserves are at comfortable levels.

"Monetary conditions are stable. Interest rates have declined and credit growth has shown signs of recovering. The central bank's policy stance remains appropriate, although there may be need to tighten it if credit and inflationary pressures pick up sharply. The central 
bank has intervened in the foreign exchange market to rebuild reserves, and has allowed the exchange rate to trade within a recently widened, although still narrow band.

"Financial sector reform is in line with the program and has substantially addressed the regulatory weaknesses. The authorities' reform agenda has been broadened to include the introduction of a deposit insurance scheme, regulation of pension funds, and steps to deepen capital markets.

"Despite the weaker-than-programmed 2009 fiscal performance, the government's 2010 budget proposal, if carried out, would significantly address past fiscal slippages, mainly through comprehensive tax reforms and sizeable cuts in recurrent spending. At the same time, the budget would allow for much needed reconstruction-related infrastructure investment, while protecting the society's most vulnerable and addressing the humanitarian needs of those adversely affected by the conflict.

“The authorities' efforts to reform trade and excise taxes and the Board of Investment's tax concession regime are a signal that they recognize the importance of a broader tax base and higher revenue in achieving the program's original goals of fundamental and sustainable reduction of the deficit and the public debt. These efforts should be followed by important steps to permanently reform tax concessions and broaden the VAT and income tax bases to be introduced as part of the 2011 budget.

"To promote private investment and growth, the authorities plan to formulate a national investment strategy, which will include reforms aimed at reducing the currently high cost of doing business in Sri Lanka," Mr. Shinohara stated. 


\section{Statement by P. Nandalal Weerasinghe, Alternate Executive Director for Sri Lanka June 28, 2010}

\section{Introduction}

My authorities wish to thank the Management and Staff of the IMF for their sustained and supportive engagement with Sri Lanka and, in particular, the Mission members for useful discussions held in Colombo during 12-21 May 2010 leading up to the comprehensive report recommending the completion of the $2^{\text {nd }}$ and $3^{\text {rd }}$ Reviews of the SBA. The SBA was approved in July 2009 at a crucial juncture of Sri Lanka's history when recovery was just beginning to set in following the knock on effects of the global economic crisis and the end to the three decade long internal conflict, which had seriously undermined Sri Lanka's development potential. The SBA played a catalytic role in the restoration of much needed investor confidence and in supporting policies for achieving and maintaining macroeconomic stability and economic growth. The completion of the first review on $6^{\text {th }}$ November 2009 was followed by the Presidential and Parliamentary elections held in January and April 2010, respectively, in which the people of Sri Lanka overwhelmingly endorsed the social and economic developmental strategy laid out by the ruling party (Mahinda Chintana: Vision for the Future). The ruling party obtained a sizeable majority at the Presidential election and almost two-thirds majority in the Parliamentary election. Political and economic stability and an environment of reconciliation, rehabilitation, reconstruction and reintegration have ushered in a new era of economic resurgence, opportunities and challenges. My authorities wish to place on record their appreciation for the support extended by the Executive Board and Management of the IMF through challenging times. My authorities, despite the relatively comfortable position that they have progressed to, remain committed to the successful completion of the SBA and to continuing the productive engagement with the Fund in the journey towards a prosperous and peaceful Sri Lanka.

\section{Overall Macroeconomic Developments}

The adverse impact of the global economic crisis was reflected in Sri Lanka's economic growth that slowed down to 3.5 per cent in 2009 from an average of around 6.5 per cent during 2004-2008. The economy recovered strongly to record a growth of 6.2 per cent in the fourth quarter of 2009 and is expected to strengthen further by growing by around 6.5 per cent in 2010 and 7-8 per cent in the medium term. Pre-emptive tightening of monetary policy has delivered in terms of stabilizing inflation, with the average inflation of 12 per cent during 1978-2008 falling sharply to 3.4 per cent by end 2009. Large capital inflows, steady flow of remittances and a surge in tourist earnings have increased Sri Lanka's official external reserves to a comfortable level of six months of imports. The fiscal deficit, which averaged around 9.5 per cent of GDP during 1978-2004, was brought down to an average of 7.0 per cent during 2005-2008 and increased to 9.9 per cent in 2009. The debt to GDP ratio was brought down from a peak of 105 per cent in 2002 to 81.4 per cent of GDP by end 2008 though it increased to 86 per cent in 2009 largely due to the lower nominal GDP growth. The improvements in social indicators, such as mortality rates, life expectancy, educational attainment, access to safe drinking water, poverty as well as gender equality over the years 
have well positioned Sri Lanka towards achieving the Millennium Development Goals (MDGs).

\section{Fiscal Policy}

The year 2009 was exceptional for fiscal policy the world over given the global crisis. Sri Lanka was, by no means an exception. Higher than expected capital expenditure and interest payments explain a major part of the expenditure over-run in 2009. Revenue collection was lower than expected mainly due to the significant slowdown in domestic economic activity and, particularly, shrinking of imports in 2009. In addition, my authorities had to deal with significant fiscal costs of resettling IDPs, providing them with basic facilities such as temporary shelter, food, medicine, demining their villages and rebuilding houses, hospitals and schools. An overriding priority was to ensure unimpeded provision of social services such as health, education and social safety nets for low income sections of the society while implementing much needed infrastructure development in all parts of the country, especially in the recently liberated Northern and Eastern provinces. Consequently, the fiscal deficit expanded to 9.9 per cent in 2009.

My authorities recognize the critical importance of fiscal consolidation in anchoring macroeconomic stability and in creating the conditions for high growth. Structural reforms in the tax system are envisaged for sustaining growth in tax revenue. The Board of Investment (BOI) has been requested to refrain from granting new tax concessions with a view to widening income and trade tax bases. Several high and prohibitive import taxes have been reduced and the import duty structure has been simplified with a view to increasing tax buoyancy and improving tax administration. Import duties on raw materials, machinery and equipment have been reduced instead of the earlier practice of providing tax exemptions only for BOI firms. These measures are expected to improve compliance and, generate higher revenues, while supporting higher investment and growth. The Presidential Tax Commission has recommended several reforms to address distortions in VAT and income taxes which are under consideration in the designing of the next wave of tax policy initiatives of the government, which are planned to be implemented with the 2011 budget as indicated in my authorities' LOI.

On the expenditure side, the cessation of hostilities has paved the way for a reduction in direct defence expenditure by $1 / 2$ per cent of GDP during 2010. Salaries and wages which constitute about 70 per cent of the defence expenditure are not expected to decline in the short term. However, most of the defence personnel are actively involved in reconstruction activities in the Northern and Eastern provinces. Total reduction in non-interest recurrent expenditure is expected to generate savings of more than one per cent of GDP. However, my authorities have given priority to rebuild basic infrastructure in the conflict-affected areas as soon as possible. Despite these challenges, my authorities have committed to a path of fiscal consolidation. The budget 2010 which will be presented to the Parliament this week expects to reduce the fiscal deficit to 8 per cent, while the 2011 budget to be presented in November 2010 aims at reducing the fiscal deficit to 6.8 per cent in 2011 and to 5 per cent by 2012. The key to achieving such targets are 1) successful implementation of tax reforms 
including reforms of VAT and income taxes together with higher economic growth, 2) rationalization of tax incentives 3 ) restraining non-interest recurrent expenditure

4) maintenance of low inflation and interest rate regime to contain interest expenditure.

5) reforms in state owned enterprises. My authorities have already commenced

implementation of some reforms and will continue the process through the Budget 2011.

Details of further tax reforms will be discussed at the next review.

The fiscal performance during the early part of 2010 is encouraging. Revenue has increased by 26 per cent, while expenditure increased only by 2 per cent during the first three months of 2010. This performance has helped my authorities to meet fiscal targets set for the first quarter of 2010 under the current Fund program. Policies and targets set for the rest of the year are expected to be maintained, given the positive trend. The process of improving the performance and the efficiency of state own enterprises (SOEs) have been strengthened by the establishment of a separate Ministry focusing on under-performing state assets and lossmaking enterprises. Management of key public enterprises has been reconstituted by appointing private sector entrepreneurs to manage these enterprises. A committee has been appointed to introduce an innovative power tariff structure by addressing distortions in the current structure, while encouraging usage of low cost power during off-peak hours. At the same time, shifting to low cost power generation is progressing with the accelerated construction of coal and hydro power plants and the development of alternative energy sources. The restructuring of the outstanding debt of the Ceylon Electricity Board is also expected to improve the financial position of the Ceylon Petroleum Corporation, significantly.

\section{Monetary and Exchange Rate Policy}

Prudent monetary policy has brought down inflation from a peak of 28 per cent on a year-onyear basis in June 2008 to 0.7 per cent by September 2009. The sharp deceleration in inflation has enabled the easing of the monetary policy stance. In 2009, the Central Bank removed the penal rate of interest on Reverse Repurchase transactions and reduced Repurchase and Reverse Repurchase rates by 300 and 225 basis points, respectively. Consequently, the 91-day Treasury bill rates have declined from high levels of above 20 per cent at beginning 2008 to around 8 per cent by mid June 2010. Other market interest rates have also followed a similar trend. Private sector credit, which contracted during much of 2009 due to the slowdown of economic activity and the lagged effect of a tight monetary policy stance, has recorded a positive growth since March 2010. The low interest rate structure and improved investor confidence have contributed positively to the recovery in private sector credit growth. My authorities are committed to maintaining inflation at a low and stable level in the future and stand ready to take appropriate monetary policy action if inflationary threats emerge.

My authorities remain committed to maintaining a flexible exchange rate regime with limited intervention to prevent wide fluctuations. Since net foreign exchange inflows continue, the Central Bank has been absorbing excess foreign exchange on net basis to prevent undue volatility in the foreign exchange market. 


\section{Financial Sector}

Despite the global financial turmoil, the domestic financial sector remained sound and resilient due to a strong regulatory framework and minimal exposure to financial derivatives. Non-performing loans (NPLs) of the banking sector, which were increasing since early 2009 due to slowing economic growth, are starting to decline from a peak of about 9 per cent in 2009. The stock market indices have increased by about 38 per cent since end -December 2009 with the All Share Price Index (ASPI) reaching an all time high in June 2010.

Swift actions by the Central Bank stabilized a systemically important licensed commercial bank (Seylan Bank) which was affected by failure of one of the companies in the Ceylinco Group, a large financial conglomerate in Sri Lanka. The capital adequacy and liquidity levels of this bank have now significantly improved and share price of this bank has increased by 125 per cent from the price at which new shares were issued to raise capital in September 2009. My authorities' timely intervention also helped to stabilize the non-bank financial entities connected to this conglomerate.

To further strengthen the soundness of the financial sector, my authorities have prepared necessary legislation for financial sector regulatory reforms as set out in the structural benchmarks. Amendments to the Banking Act are expected to be submitted to the Parliament by end September 2010, while amendments to the Finance Companies Act would be submitted to the Parliament shortly. Prudential regulations for credit card companies and payment service providers have already been issued and the Central Bank intends to issue guidelines to improve banks' integrated risk management frameworks by end-July 2010. The Central Bank has also announced a number of reform initiatives, including the implementation of a mandatory deposit insurance scheme, regulation of pension funds and measures to further develop corporate debt and equity markets.

\section{Post-Conflict Reconstruction and Development of the Northern Province}

By the time of the last review in November 2009, my authorities had fully resettled all IDPs in the Eastern Province and restored normalcy in the province with democratically elected provincial administration. Similar processes have been initiated in the Northern Province with the highest priority accorded to demining operations and providing basic humanitarian assistance to IDPs. In parallel, basic infrastructure facilities such as roads, hospitals, schools, government administration structures and local governments elected by people in the area have been developed. These efforts have yielded very positive results. Only 50,000 IDPs remain to be resettled in their villages in the Northern Province. They are also now free to move in and out of welfare centers. Major road access linking the North and the South has been reconstructed and opened for free movement of people, goods and services. As a result of the higher integration of Northern and Eastern provinces with the other provinces, agriculture, tourism, fishing, transport, telecommunication, banking and other economic activities are expanding rapidly. With the support of bilateral and multilateral partners, my authorities intend to complete the final phase of resettlement by end August 2010. Developing major infrastructure will continue into the next couple of years. Many bilateral 
and multilateral agencies including China, India, Japan, the ADB and the World Bank have already committed significant amounts of financial assistance for various infrastructure and livelihood development programs in the Northern Province.

\section{Program Design}

Since the completion of the first review for meeting end-July 2009 performance criteria, my authorities have shown full commitment to the SBA by achieving all performance criteria and almost all structural benchmarks for end September 2009, end December 2009 and end March 2010 except for the end December 2009 NDF target. If there were no elections, the additional 3 reviews would have been completed and my authorities would have been able to purchase at least three tranches (SDR 620 million) according to the original schedule. In view of the delay in achieving the fiscal policy objectives of the program, my authorities have agreed to extend the SBA by another 12 months and purchase only two revised tranches (SDR 275 million), while re-phasing the balance tranches for the remaining period of the SBA. 